\title{
Imagining the Stars
}

\section{The Miniatures of the Natuurkunde van het Geheelal in the Herzog August Bibliothek in Wolfenbüttel}

\author{
Klara H. Broekhuijsen | ORCID: 0000-0003-4499-1363 \\ University of Amsterdam, Amsterdam, the Netherlands \\ k.h.broekhuijsen2@contact.uva.nl
}

\begin{abstract}
The Natuurkunde van het Geheelal in Wolfenbüttel, which was made in Utrecht around $1465^{-1470}$ is a text about celestial bodies and meteorological and natural phenomena. Most copies of this text are clarified by astronomical drawings and diagrams. The manuscript in Wolfenbüttel, however, also contains miniatures with the personifications of the seven planets and the signs of the zodiac. The author's aim is to find the source of inspiration for the unusual pictures of the planets in particular, and also for the signs of the zodiac.
\end{abstract}

\section{Keywords}

Natuurkunde van het Geheelal - Dutch manuscript illumination - Master of Evert Zoudenbalch

The library in Wolfenbüttel has an exceptional copy of an anonymous encyclopedic work in verse on the cosmos titled the Natuurkunde van het Geheelal (The Nature of the Universe). ${ }^{1}$ This astrological text in Middle Dutch, which may

1 I am greatly indebted to Anne Korteweg for her comments and valuable suggestions about the first version of this text. I would also like to thank Anne Margreet As-Vijvers, Dieter Blume, Sophie Jolivet, Orlanda Lie, Eric Moormann, Bernhard Ridderbos and Rob Scheller for their answers to a wide variety of questions. I am grateful to Willem van Bentum and Noor Versélewel de Witt Hamer for answering my queries about the text, Ed van der Vlist for his observations on the script, and Ilse Geelen-Slot for her translation of Scotus's text on the appearance of the planets. My thanks, too, to Michael Hoyle for correcting my English. 
have originated in Ghent or thereabouts at the end of the thirteenth century, has been preserved in ten different copies from the period c. $1375^{-}$c. 146o. No direct source for the text, which is based on the ideas of Aristotle, Ptolemy, and Alfarganus, has survived, but it may have been a Latin manuscript that also formed the basis of the Image du Monde of c. 1245 by the French priest Maitre Gossouin. ${ }^{2}$ The Natuurkunde van het Geheelal not only focuses on the planets and other celestial bodies, but also deals with meteorology and natural phenomena such as earthquakes. ${ }^{3}$ Almost all of the manuscripts have drawings and diagrams, some coloured, some not, that aim to clarify these natural phenomena. Unlike the other manuscripts with this text, the Wolfenbüttel copy not only features astronomical drawings and diagrams, but is also the only one with miniatures depicting the seven planets, the twelve signs of the zodiac and stars, comets, and natural phenomena. The planet series is particularly interesting.

The Wolfenbüttel Natuurkunde van het Geheelal is preceded by instructions on phlebotomy (bloodletting), decorated with a full-page coloured drawing of a bloodletting Zodiac Man, a Latin Computus, and a versified Computus (Cisiojanus) in Latin and Dutch. The text of the Natuurkunde van het Geheelal is followed by a few pages with medical prescriptions and rules for punctuation. Today the manuscript with these texts is enclosed in a simple parchment binding, possibly from the seventeenth century, together with manuscripts with one long and three short descriptions of the Holy Land by Willem Waltersz. van Zierikzee and a description of a pilgrimage by Odericus de Pordenone. Since there is a fifteenth-century ink foliation in several places in the lower margin of the texts about phlebotomy, the Computus and the Natuurkunde marking the leaves of each section, and a difference between the writing hands of these texts from those of the travel descriptions, not all the texts could have been together in a single volume from the outset, but were bound in at a later

For a digital version of the Wolfenbüttel manuscript, Herzog August Bibliothek, Cod. Guelf. 18.2 Aug. qu.: see http://diglib.hab.de/?db=mss\&list=ms\&id=18-2-aug-4f\&lang=en, last accessed 21 June 2021.

2 For an extensive discussion of the possible sources see R. Jansen-Sieben, De Natuurkunde van het Geheelal. Een 13 de-eeuws middelnederlands leerdicht (Brussels 1968), pp. 66-87. In her introduction to the text edition of the Uppsala manuscript she briefly discusses the ten surviving manuscripts on pp. 88-163.

3 Jansen-Sieben, op. cit. (n. 2), pp. 21-23 contains an overview of the topics discussed. These are not dealt with in the same order in all the manuscripts. See p. 252 for an overview of the contents of the various manuscripts. She considers the one in Wolfenbüttel to be exceptional because of the miniatures, the Latin texts, the inserted Middle Dutch verses and the incomplete text of the Natuurkunde. Jansen-Sieben, op. cit. (n. 2), p. 249. 
date and must be considered as separate codicological units (see the Appendix with the codicological description).

The Wolfenbüttel manuscript is the youngest of the surviving ones with the text of the Natuurkunde van het Geheelal, and can be traced back to Utrecht on the evidence of linguistic features common to the cathedral city and the eastern part of the Utrecht diocese, to the illumination of the Utrecht Master of Evert van Zoudenbalch, who was active between 1460 and 1470, and to the two penwork initials at the beginning of the text on phlebotomy and the Latin Computus. They are in the manner of so-called Crown and Dragon penwork, which is common in Utrecht manuscripts of that period. ${ }^{4}$

A brief discussion of the miniaturist and his oeuvre prefaces an overview of representations of planets in the Middle Ages. This is followed by research into the special iconography of planets in the Wolfenbüttel manuscript and its possible origin. The signs of the zodiac there will also be explored, as will the painted diagrams and small miniatures of the astronomical and meteorological subjects. Finally, the focus will shift to the miniature of the bloodletting Zodiac Man that accompanies the phlebotomy instructions, and to a brief discussion of the question for whom this manuscript could have been made.

\section{The Master of Evert Zoudenbalch}

The so-called Master of Evert Zoudenbalch, who is responsible for the majority of the miniatures in the Natuurkunde van het Geheelal, was one of the most important book illuminators of the third quarter of the fifteenth century in Utrecht. This anonymous illuminator owes his acquired name to Evert Zoudenbalch (c. 1425-1503), canon of Utrecht Cathedral, who commissioned a two-volume Bible produced around $1460 .{ }^{5}$ Besides a large number of the miniatures in the first part of this Bible, which is now in Vienna, the Master of Evert Zoudenbalch mainly painted full-page miniatures for books of hours. His work is characterized by elegant female figures with round faces, dressed in beautifully pleated robes. The men have slightly less rounded faces and are usually well-dressed as well. The Master of Evert Zoudenbalch was fond of placing

4 G. Gerritsen-Geywitz, Het Utrechtse draakje en zijn entourage. Vijftien penwerkstijlen in Utrechtse handschriften en gedrukte boeken uit de tweede helft van de vijftiende eeuw (Hilversum 2017), pp. 45-56.

5 Vienna, Österreichische Nationalbibliothek, Cod. 2771-2772. J. H. Marrow et al., The Golden Age of Dutch Manuscript Painting (Utrecht/New York 1989-199o), cat. no. 61. 
his figures in deep landscapes with atmospheric perspective, or carefully constructed interiors with tiled floors and beamed ceilings correctly rendered in perspective. He painted in bright colours, with deep red, blue, green and bright pink predominating. His compositions, which often give the impression of small panels, sometimes show influences from Jan van Eyck and the Master of Catherine of Cleves. He not only worked as a miniaturist, but also as a panel and mural painter. Two panels with a Crucifixion and a mural with the Tree of Jesse in the Buurkerk in Utrecht are attributed to him. ${ }^{6}$

The manuscript in Wolfenbüttel occupies a special place within the oeuvre of the Zoudenbalch Master. He mainly illuminated religious books made of parchment, while the Natuurkunde is a simple manuscript made of paper. Stylistically, though, the miniatures fit in well with the rest of his work. The personifications of the planets and human signs of the zodiac have the same kind of faces and wear similar elegant robes as the figures in the Vienna Bible. Because painting on paper requires a different method from that on parchment, delicate coloured hatching was used for the modelling of the figures and their clothing. The miniatures accordingly tend to look more like drawings. The thin layers of paint also reveal parts of an underdrawing, and in many cases the white surface of the paper shows through in the light passages. As far as subjects are concerned, the miniatures with the personifications of the planets are unique, and there is no comparison within Dutch manuscript painting. The signs of the zodiac also appear in a miniature in the Vienna Bible. Prior to the book of Genesis, the Master of Evert Zoudenbalch painted a fullpage representation of the Ptolemaic universe for that Bible. ${ }^{7}$ According to this model, the Earth is the centre of the cosmos, around which the planets run in concentric circles. The outer ring is formed by the firmament with the fixed stars or the zodiac, above which God is enthroned, surrounded by his choirs of angels (Fig. 1). In the sphere of the firmament, the signs of the zodiac are presented in much the same way, but far smaller, as in the miniatures of the Natuurkunde van het Geheelal.

Since the Wolfenbüttel manuscript is not only a Fremdkörper within the work of the Zoudenbalch Master, but is also unique within northern Netherlandish manuscript painting, an investigation into the iconography of

6 For the panels in Providence and Utrecht see D. G. Carter, 'The Providence Crucifixion. Its Place and Meaning for Dutch Fifteenth Century Painting', Bulletin of the Rhode Island School of Design, 48 (1962), pp. 1-40 and K. Hazelzet, Een schilderij centraal. Het Utrechtse Kruisigingsdrieluik en de aanblik van de hostie (Utrecht 1979). For the heavily damaged mural of the Tree of Jesse: K. G. Boon, 'Een Utrechtse schilder uit de vijftiende eeuw, de Meester van de Boom van Jesse in de Buurkerk', Oud Holland, 76 (1961), pp. 51-6o.

7 Vienna, Österreichische Nationalbibliothek, Cod. 2772, f. 9 r. 


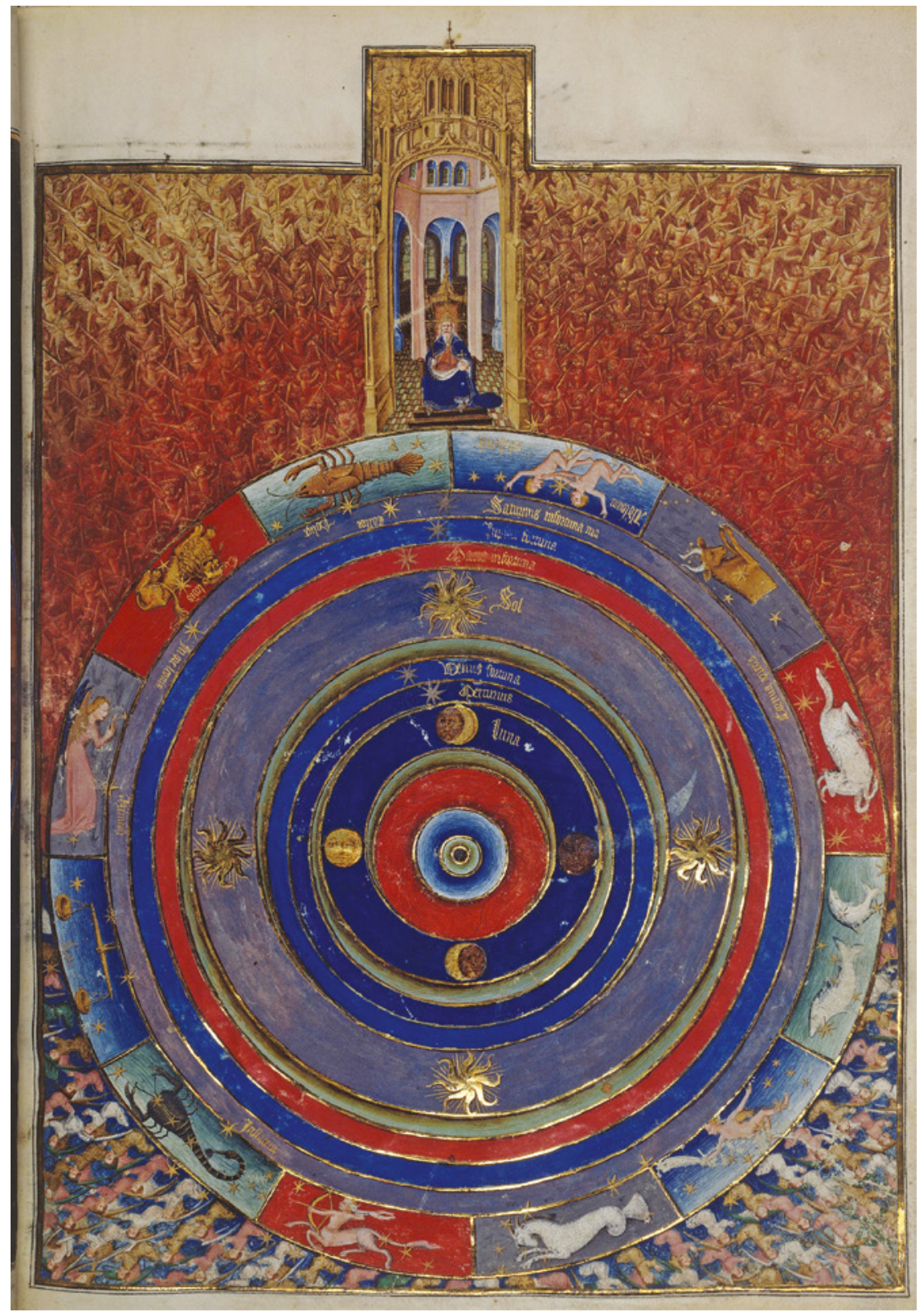

FIGURE 1 Master of Evert Zoudenbalch. God the Father enthroned above the celestial sphere with the planets and the signs of the zodiac. Vienna, Österreichische National Bibliothek, Cod. 2771, f. gr (C): VIENNA, ÖSTERREICHISCHE NATIONAL BIBLIOTHEK 
the planets and the signs of the zodiac requires a search for comparative material outside the northern Netherlands. The standard work in this area is Dieter Blume's Regenten des Himmels, in which the depiction of the planets is also discussed in media other than illuminated books. An important source for the signs of the zodiac is the catalogue of astrological manuscripts from the period 1200-1500, Sternbilder des Mittelalters und der Renaissance, of which Blume is one of the co-authors. ${ }^{8}$

\section{Representations of the Planets in the Middle Ages}

In contrast to authors from the first four decades of the twentieth century, who saw a continuous development in the afterlife of astrological representations from antiquity until the Renaissance, Dieter Blume points out that there is no question of continuity in the imagination of the planets, but an interrupted tradition. ${ }^{9}$ He observes that, rendered in a highly simplified manner, astrological representations developed and adapted from the thirteenth century onwards in a continuous interaction between court culture and urban culture, between illuminated manuscripts and other media, like mural painting and sculpture. ${ }^{10} \mathrm{He}$ argues that astrology was rediscovered in the twelfth century when older astrological texts, such as those of the Persian astrologer Abu Ma'shar (787-886), were translated from Arabic into Latin. For instance Georgius Zothorus Zaparus Fendulus, an otherwise unknown astrologer, adapted Abu Ma'shar's Introductorium maius in astronomiam based on an older Latin translation by Hermann of Dalmatia (c. 1100-c. 116o). ${ }^{11}$ There is an extant, richly illuminated manuscript of this compilation of Abu Ma'shar's text by Fendulus dating from around $1230 .{ }^{12}$ That Liber astrologiae originated at

8 D. Blume. Regenten des Himmels. Astrologische Bilder in Mittelalter und Renaissance (Berlin 200o); D. Blume, M. Haffner and W. Metzger, Sternbilder des Mittelalters und der Renaissance. Der gemalte Himmel zwischen Wissenschaft und Phantasie. II. 1200-1500 (Berlin/Boston 2016).

9 Blume, op. cit. (n. 8), pp. 8-17. One of the most authoritative scholars of that period on this subject is Fritz Saxl. For an evaluation of his ideas see R. Duits, 'Reading the Stars in the Renaissance. Fritz Saxl and Astrology', Journal of Art Historiography, 1.5 (2011), pp. $1-18$.

10 Blume, op. cit. (n. 8), p. 198.

11 Herman of Dalmatia (Carinthia) produced the Latin translation of Abu Ma'shar's work between 1140 and 1143 as part of a larger project. Blume, op. cit. (n. 8), p. 22.

12 Paris, Bibliothèque Nationale, Ms. lat. 733o. Blume, op. cit. (n. 8), Pls. 1-11, Figs. 17-46, and https://gallica.bnf.fr/ark:/12148/btvib9o6829oj, last accessed 21 June 2021. 
the court of Emperor Frederick II (1194-1250) in southern Italy, which was an important centre for the arts and sciences, especially astrology. The planets in that work are each depicted in four miniatures, showing six different positions relative to the zodiac. Influenced by the descriptions in the Cosmographia (c. 1140) of Bernardis Silvestris, which has not come down to us in any illuminated manuscripts, they are shown both as kings and rulers with crown and sceptre on a throne, and in positions in which they have little or no power and fall from their throne. In addition to a sceptre, they also have an attribute that sometimes refers to the area over which they 'rule'.

Somewhat later, between 1230 and 1240, Michael Scotus (before 1200-c. 1232), also at the court of Frederick II, wrote a very influential astrological treatise, Liber introductorius which remained popular until the end of the fifteenth century. In it he incorporated much of the older astrological knowledge and gave extensive descriptions not only of the celestial bodies but also of such natural phenomena as storms and lightning. Scotus devised new descriptions for the appearance and attributes of the planets, which also seem to embroider a little on Fendulus. For example, Scotus described Mercury as a scholar, also referring to science, the field in which Mercury has influence. Venus has been proposed as a grand, smartly dressed young woman smelling a rose as a reference to love, while Mars is equipped with a helmet, all kinds of weapons and a breastplate as a thirteenth-century warrior. Jupiter has the appearance of a wealthy citizen, judge or bishop, and is dressed in a fur-trimmed cloak with a girdle, from which a purse hangs, and with flowers or a sceptre in hand. Saturn is an old man in armour holding a sickle, the only attribute borrowed from antiquity, which is also a reference to the farming business he rules. Speaking of Sol, Scotus says that he is in a four-in-hand and holds a torch with three flames in his right hand as a reference to the Trinity. He also has a halo around his body. Finally Luna, a young woman with a crescent moon on her head, is seated in a chariot drawn by two horses and is holding two burning candles or torches. Because most of the planets also represent a certain social group, they were easily recognizable for the viewer. ${ }^{13}$

Although the illuminated manuscripts of Scotus's text probably originated in southern Italy, the oldest surviving copies are from northern Italy, where they were known in the early fourteenth century Padua, as evidenced by the work of the astrologer Pietro d'Abano, who was a physician and astrologer at

13 Blume, op. cit. (n. 8), pp. 52-63. For the original text of Scotus's descriptions see Appendix 6, pp. 223-25, with thanks to Ilse Geelen-Slot for her translation of the Latin text. 
the university there. ${ }^{14}$ Between 1315 and 1317 Giotto created a fresco cycle in the Palazzo della Ragione that was inspired by Pietro's astrological theories. Those frescoes, which were painted over and expanded after Giotto's original design after a fire in 1420, consist of an extensive programme of the seven planets, the signs of the zodiac and the works of the month. The planets are represented with a large golden star behind the body or behind the head as a sign of their status as major celestial bodies. A reddish gold mandorla was added to Sol. Around 136o the Paduan artist Guariento di Arpo also painted the planets in a similar way in the church of the Eremitani in Padua, combining them with the ages of man. Like Giotto, he painted his planets against the backdrop of a large star. Both Giotto and Guariento made use of existing iconographic motifs, such as a mirror for Venus, an attribute already known from Luxuria, or a lectern derived from the one used by scholars for Mercury. ${ }^{15}$

From the middle of the fourteenth century there was also a growing interest in astrological texts north of the Alps, and a replica of the oldest Fendulus manuscript from the court of Frederick II was created in Flanders or Burgundy. The thirteenth-century manuscript was not copied literally, but was updated by giving the planets additional and more specific attributes and by dressing them in contemporary garb. For example, in a version of Fendulus's Liber astrologiae of about 1350, Mercury not only has a book but also a lectern and is dressed as a cleric, since medieval scholars were usually clergymen. ${ }^{16}$ Something similar also applies to Saturn, who has a spade in addition to his sickle, emphasizing his occupation as a farmer.

A copy of the manuscript that originated in Flanders or Burgundy was made in Bruges before 1403 and given to Jean de Berry as a gift. ${ }^{17}$ Jean de Berry's

14 For a detailed discussion of the development and interdependence of fourteenth-century manuscripts see Blume et al., op. cit. (n. 8), pp. 46-53.

15 Guariento's frescoes in the Church of the Eremitani in Padua are only partially preserved as a result of bombing in 1944. Luna, Mercury, Venus and Sol survive in their original condition; Mars, Jupiter and Saturn are known only from earlier black-and-white photographs. For images see Blume, op. cit. (n. 8), Pls. 23-26 and Figs. 112-14. An astrological manuscript from the first half of the fifteenth century, showing the influence of both the paintings in the Palazzo della Ragione and Guariento in the church of the Eremitani, shows Venus with a mirror in her hand against the background of a star. See Modena, Biblioteca Estense, Ms 697, ff. 3v and 6v (Blume, op. cit. (n. 8), Figs. 117 and 118).

16 London, British Library, Ms Sloane 3983. For a short description of the manuscript and an overview of the miniatures see Blume et al., op. cit. (n. 8), cat. no. 2 and https:// www.bl.uk/catalogues/illuminatedmanuscripts/record.asp?MSID $=7959 \&$ CollID $=9 \& N S t$ art $=3983$, last accessed 21 June 2021. The example for this manuscript is Paris, Bibliothèque Nationale, Ms. lat. 7330, which was in the north from at least around 1500 . See also n. 12.

17 New York, The Morgan Library \& Museum, M. 785: http://ica.themorgan.org/manuscript/thumbs/144038, last accessed 21 June 2021; Blume et al., op. cit. (n. 8), cat. 
interest in astrology is also evident from the calendar cycle and the miniature of the zodiac in his Très Riches Heures. ${ }^{18}$ In his library there were other illuminated manuscripts that contributed to the iconography of the planets, such as the Ovidius moralizatus (1340) by Petrus Berchorius, the Genealogia deorum Gentilium (1360) by Boccaccio, and the Epistre d'Othéa by Christine de Pizan. In this allegorical text from 1400-01, in which Othéa, the imaginary goddess of Wisdom, instructs the Trojan hero Hector how to behave, ancient gods, including the planets, are presented as exempla. In accordance with the text, the personifications of the planets are always represented sitting on a rainbow in the company of people who were born under their influence. Representations of this kind developed into depictions of the planets and their 'children' in the course of the fifteenth century, particularly at the beginning of the century in German-speaking regions. Many of those astrological-cum-astronomical texts, especially those by Scotus, persisted into the sixteenth century. They were not always in the form of translations, but were often adaptations in the vernacular that were intended for a lay audience in the cities. ${ }^{19}$ A good example of this are the so-called planetary poems, which also began appearing in the form of a block book with woodcuts around 143 o. Below the text they have the planets on one leaf and on the opposite leaf the 'planet children', the people whose destiny they determine. The personifications of the planets are here depicted naked with a star concealing their genitalia and with attributes that partly originate from classical times, such as a money pouch for Mercury and a mirror for Venus. No direct predecessors can be identified for this new iconography, which also emerged in Italy in the mid-fifteenth century.

The first half of the fifteenth century saw the appearance of 'Hausbücher', almanacs with miscellaneous contents, which included astrological and medical information, a kind of practical manuscripts for household use that were often written on paper in a rapid bastarda. An early representative of this genre is the 1445 Passau Calendar, a compilation of a perpetual calendar with information on determining the date of Easter and other calculations, and

no. 4. This manuscript served in turn as an example for new copies that were made in the Burgundian-Dutch area or France. Blume op. cit. (n. 8), p. 150. Those new copies are Paris, Bibliothèque Nationale, Ms lat. $733^{1}$ dated around 1450, which also originated in Bruges(?) and two manuscripts made in France around 1450 and c. 1500: Paris, Bibliothèque Nationale, Ms lat. 7344, which is in a slightly different visual tradition, and MS Smith-Lesouëf 8, which is related to Ms lat. 7331. See Blume et al., op. cit. (n. 8), p. 22 and cat. nos. 5, 6 and 7. With thanks to Anne Korteweg for the references.

18 H. Bober, 'The Zodiacal Miniature in the Très Riches Heures of the Duke of Berry: Its Sources and Meaning', Journal of the Warburg and Courtauld Institutes, 11 (1948), pp. 1-34.

Blume, op. cit. (n. 8), p. 161. 
medical and astrological treatises. The treatise on the planets features miniatures depicting the planets derived from those in the Basel block book, except that the planets are no longer naked and their 'children' are below them. The planets are contained in a separate medallion, which is flanked by smaller medallions with the signs of the Zodiac serving as their homes. Below, twothirds of the space was left for the 'children' and their activities. ${ }^{20}$

Representations of personified planets have a long tradition and occur in all kinds of media, including illuminated manuscripts and early editions of various texts.

\section{The Seven Planets in the Natuurkunde van het Geheelal in Wolfenbüttel}

The text of the Natuurkunde opens with a comment on the influence of the planets on human beings, followed by information regarding the calendar, such as the times of the quatertemper days (penance days) and the calculation of the date of Easter and the like. This is followed by general remarks on the planets, including a discussion of their cosmic houses. Subsequently, the seven planets (ff. 122v-27r) are discussed in short texts that usually run to about ten lines per planet and in which information is given about the distance of the planet in question from the earth. To this the copyist has always added a short Latin text, which discusses the planet in accordance with the doctrine of the humores, the four bodily fluids of blood, yellow bile, black bile and phlegm, which determine the state of a person's mind. ${ }^{21}$ These Latin texts, which do not occur in the other Middle Dutch manuscripts of the Natuurkunde van

20 For developments in the German-speaking region see Blume, op. cit. (n. 8), pp. ${ }^{15}{ }^{-}$ 67. For the Passau Calendar see M. Müller, Beherrschte Zeit. Lebensorientierung und Zukunftgestalt durch Kalenderprognostik zwischen Antike und Neuzeit. Mit einer Edition des Passauer Kalendars (UB, LMB 20 MS astron.1) (Kassel 20o9; thesis Göttingen 2006). http://www.uni-kassel.de/upress/online/frei/978-3-89958-296-3.volltext.frei.pdf, last accessed 21 June 2021.

21 The Latin texts display similarities to descriptions of the planets in the Tractatus de crisi et de diebus creticis (1295) by the physician Bernardus Gordonensis (1270-1330), who was associated with the University of Montpellier. This treatise on the course of diseases and the critical moments during an illness was very popular in the Middle Ages. Bernardus stresses that the influences of the planets must be taken into account. See: http://mlat. uzh.ch/?c=4\&w=BerGor.TrDeCri, last accessed 21 June 2021: click on pars quinta and then on capitulum $8 \mathrm{~m}$. I am grateful to Andrea van Leerdam for mentioning this reference in her transcription. 
het Geheelal, are indented and written in a slightly smaller script by the same hand. ${ }^{22}$ The copyist left space for a square, column-wide miniature for each of the planets. For this he initially reserved the top half of the page and left instructions for the miniaturist, some of which can still be read. The depiction of Luna on f. 123r is accompanied by a small crescent moon in the left margin, and the names 'venis' and 'sol' written to the left of the miniatures of Venus and Sol on f. 124r and f. 125r. The copyist may then have discovered that this layout would result in pages that left half blank, as is the case with f. 124v, prior to Sol. He accordingly planned the next three miniatures on the bottom half of the page. In the case of Saturn, there is a clue to the miniaturist in the form of the name 'saturnus' beside the miniature. ${ }^{23}$ Repositioning the miniatures in the bottom half of the page did not always work out well, because the copyist left so little space for the illuminator in the case of two of the three miniatures that he was obliged to use part of the bottom margin. This also had consequences for the red, Middle Dutch captions, which are not always below the miniature, but in the case of Jupiter and Saturn have ended up on the next page. The caption for the Venus miniature is also somewhat unfortunate, because too little space was left for it, so that it appears to have been squeezed between the miniature and text, giving the impression that it was added later. Comparison of the red lines written in hybrida at the miniatures and the red rubrications in the text, also in hybrida, shows that both are by the same hand. ${ }^{24}$ It can therefore be deduced that the miniatures in the Wolfenbüttel Natuurkunde were probably painted after the text was written, with the red captions and the rubrication only then being added to the text. ${ }^{25}$ That would account for the cramped caption for Venus, for which the copyist had apparently forgotten to leave enough space. It is unclear, though, why he wrote the Middle Dutch text for Luna prior to the miniature, thus departing from the order miniature, caption in red, Middle Dutch text, Latin text, which he invariably followed for the other planets. Perhaps he had initially forgotten

\footnotetext{
22 Thanks to Ed van der Vlist for this observation.

23 I am grateful to Willem van Bentum for drawing my attention to the crescent moon and the names 'venis', 'sol', and 'saturnus'.

24 With thanks to Ed van der Vlist for pointing out the similarities between some individual letters.

25 In his article on the possible relationships between the scribe and the painter regarding the execution of the initials in medieval manuscripts Peter Gumbert not only mentions that initials are delayed, because other materials were needed, but also thinks that rubrication could have been delayed for the same reason. See J. P. Gumbert, 'Times and Places for Initials', Quaerendo, 39 (2009), p. 309. My thanks to Ed van der Vlist for this reference.
} 
the Middle Dutch text about Luna or had already realized that his planned sequence would not work out well.

The short red lines characterizing the planets together form an existing medieval rhyme about the influence of the planets on a person's life, and appears to have been taken from the Roman van Heinric ende Margriete van Limborch. ${ }^{26}$

The seven planets, the names of which derived from those of the ancient gods in classical times, are represented in the Natuurkunde van het Geheelal in Wolfenbüttel as personifications set against a night-blue background and enclosed in a golden frame. All the figures are sitting or standing in front of a large eight-pointed golden star, with the exception of Luna and Sol.

The miniatures do not illustrate the text of the Natuurkunde in the sense of depicting passages from the text. Neither do the red captions and the Latin texts offer any clues as to the way in which the planets were rendered by the Master of Evert Zoudenbalch. Their order of presentation in the manuscript reflects the geocentric world view, with the Earth being the centre of the cosmos, around which the planets and stars move in circles.

The first planet to be discussed in the Natuurkunde is Luna. The miniature shows a blue face in profile that simultaneously depicts a full and a half moon because the crescent moon forms the back of the head. Standing against the background of the blue moon is an elegantly dressed woman with a long head of blonde hair falling before her eyes, holding a donkey on a rope and forcing it to tread on a wheel. It is not the usual figures of people who are depicted on the wheel but animals. A monkey is clambering up the wheel, at the top of which there is a fox with a bag of money, and on the other side a hunting dog falling down and a crowned lion beneath the wheel (Fig. 2). The wheel has led to the woman being identified as Lady Fortune, and a parallel has been drawn between the vicissitudes of fate and the waxing and waning moon. ${ }^{27}$

26 A. van Gijsen, 'Een verknipt rijmpje en de optiek van de verstrooide blik', in: Een school spierinkjes. Kleine opstellen over Middelnederlandse artes-literatuur, ed. W. P. Gerritsen et al. (Hilversum 1991), pp. 77-79. I am grateful to Orlanda Lie for this reference.

27 Marrow et al., op. cit. (n. 5), cat. no. 64, p. 209. E. Meyer-Landrut. Fortuna. Die Göttin des Glücks im Wandel der Zeiten (Berlin 1997), pp. 100-101. W. Kuiper, 'Luna en Fortuna', in: Kennis in beeld. Denken en doen in de Middeleeuwen, ed. A. van Leerdam et al. (Hilversum 2014), pp. 46-53, and W. Kuiper, 'Occasio of Fortuna?', col. 99, 11 October 2014: https:// www.neerlandistiek.nl/2014/10/column-99-occasio-of-fortuna, last accessed 21 June 2021. 


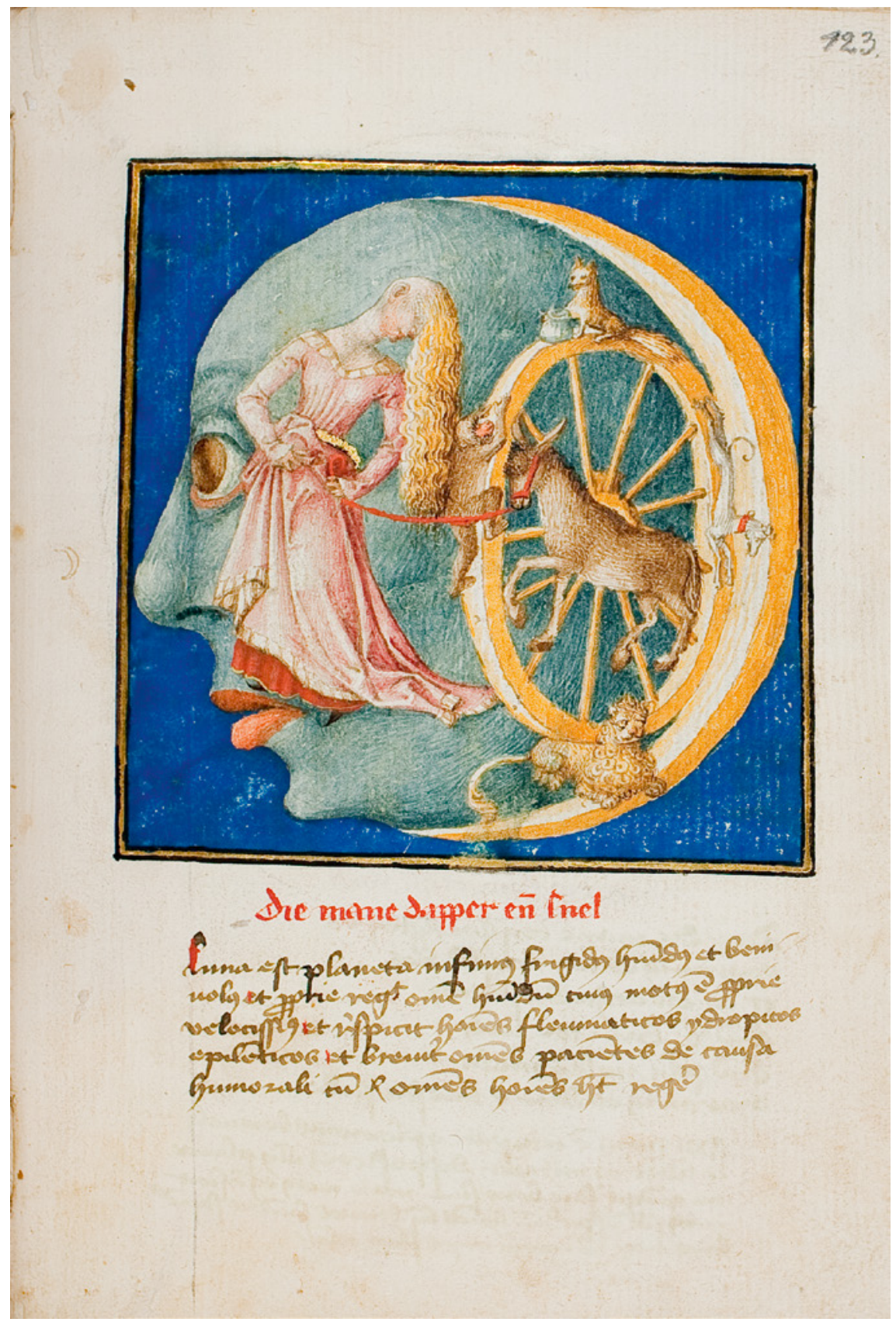

Figure 2 Master of Evert Zoudenbalch. Luna. Wolfenbüttel, Herzog August Bibliothek, Cod. Guelf. 18.2.Aug.qu., f. 123r (C): HeRZog AUgUStBibliotheK, WOLFENBÜtTEL 
The choice of animals instead of people on the wheel indicates that this is a satirical representation, in which the animals refer to vices. ${ }^{28}$ A much more explicit connection between planets and vices appears in a 1445 astrological compendium for lay people, the so-called Passau Calendar, in which the planets all bear a flag with an animal alluding to a vice. For example, Luna has a banner with a donkey on it, which not only indicates Stupiditas/Ignorantia (Stupidity/Ignorance), but also Acedia (Slowness/Laziness with regard to the performance of good works). The animals on the wheel also symbolize vices: the monkey stands for Luxuria/Vanitas (Lust/Vanity), the fox for Avaritia (Avarice) and the dog for Invidia/Ira (Envy). ${ }^{29}$ The donkey as a symbol of stupidity and laziness thus keeps the wheel with the animals (vices) turning, while the lion, the king of the beasts and a symbol of strength, lies impotently aside on the ground.

It is not only the presence of animals on and in the wheel that is special, but also the way in which Fortuna is depicted. Instead of a blindfolded woman turning the wheel, she is a woman with the back of her head bald and a face hidden behind her thick, tumbling tresses. It is a hairstyle belonging to the Fortuna who is related to Kairos/Occasio, the personification of Occasion, who has a bald back of the head and long hair hanging down from the forehead as a reference to the problem of recognizing the right moment and then seizing the opportunity. ${ }^{30}$ This Occasio hairstyle was transferred to Fortuna in Italy in the fifteenth century. Literary sources may also have played a role, such as the Dicta Catonis, which served as a textbook for Latin throughout the Middle Ages. ${ }^{31}$ In the equally popular Carmina Burana there are songs about Fortuna,

28 Meyer-Landrut, op. cit. (n. 27), pp. 96-102, and Kuiper 2014, op. cit. (n. 27), pp. 50-2. Many such satirical scenes can be found in the border decoration of manuscripts. Cf. The Hague, Royal Library, MS 78 D 40, f. 33r. https://manuscripts.kb.nl/zoom/ BYVANCKB\%3Amimi_78d40\%3Ao33r_randfig, last accessed 21 June 2021. See also L. M. C. Randall. Images in the Margins of Gothic Manuscripts (Berkeley/Los Angeles 1966), pp. 18-19. For the vices see Christliche Ikonographie in Stichworte, ed. H. Sachs (Munich/ Berlin 1998), s.v. 'Esel', 'Planeten', 'Tiersymbolik' and 'Tugenden und Laster'.

29 For an overview of the planets and the associated vices see Müller, op. cit. (n. 20), pp. 2256 , illus. in Bildteil.

30 This lives on in the English phrases 'to take time/opportunity/occasion by the forelock', meaning to seize an opportunity or arrange something without delay. For the literary sources see G. L. Kettridge, 'To Take Time by the Forelock', Modern Language Notes, 8 (1893), cols. 459-69 and K. Pietsch, 'On the Source of the Italian and English Idioms Meaning “To Take Time by the Forelock"', Modern Language Notes, 8 (1893), cols. 469-75.

31 For the history of the conflation of Fortuna and Occasio: P. Helas, 'Fortuna-Occasio. Eine Bildprägung des quattrocento zwischen ephemerer und ewiger Kunst', Städel Jahrbuch, 17 (1999), pp. 101-24. The Dicta Catonis, attributed to Cato, but by an anonymous third century author, indicates that one should seize an opportunity when it presents itself. 
who is described as having a fine head of hair, but who is bald if one decides to take a chance..$^{32}$ In addition, in one of the songs fate is compared to the changeability of the moon, showing that the connection between the moon and Fortuna has existed for much longer. ${ }^{33}$

The blue colour of the moon is also striking. Occasionally it is shown coloured blue in astrological manuscripts, for example in a late fifteenthcentury Fendulus manuscript and in the Tübinger 'Hausbuch'. ${ }^{34}$ Also there is a bluish full moon face with a crescent moon in a miniature of Luna in a medallion in the Passau Calendar. Below Luna are two other medallions: the left one shows her house, Cancer, and since Luna has only one astrological house, the other one contains a bluish full moon face and a crescent moon. ${ }^{35}$ The colour blue may also refer to the phrase 'a blue moon' for something that rarely recurs or is short-lived, and the latter certainly applies to the different phases of the moon. ${ }^{36}$ The depiction of Fortuna with her forelock against the background of the moon can therefore be understood as a lesson that one must not wait

Book II, 26, on Occasio: 'Rem, tibi quam noscis aptam, dimittere noli; Fronte capillata, post haec occasio calva' (Do not let what you consider good escape: hairy forehead, bald at the back).

32 Carmina Burana: Fortune plango vulnera stillantibus ocellis, quod sua michi munera subtrahit rebellis. Verum est, quod legitur fronte capillata sed plerumque sequitur occasio calvata (I bemoan the wounds of Fortune with weeping eyes, the gifts she made me are taken away. it is read in truth that a fine head of hair usually follows with baldness.) English translation https://lyricstranslate.com/en/fortune-plango-vulnera-16-fortunes -lamented-wounds.html, last accessed 21 June 2021.

33 Carmina Burana: O Fortuna, velut Luna, statu variabilis, semper crescis aut decrescis (Oh Fortuna, like the moon is changing, you're always growing and decreasing). English translation: https://lyricstranslate.com/en/o-fortuna-17-oh-fortune.html, last accessed 21 June 2021.

34 For a moon with a similar face in profile see the late fifteenth-century Fendulus manuscript in Paris, Bibliothèque Nationale, Ms lat. 7344, f. 6r, bottom right: https://gallica .bnf.fr/ark:/12148/btvıb10516o9o4/f15.image and Tübingen, Universitätsbibliothek, Md. 2, f. 72r and f. 79r: http://idb.ub.uni-tuebingen.de/opendigi/Md2\# $=146$, last accessed 21 June 2021. With thanks to Anne Korteweg for the references.

35 Müller, op. cit. (n. 20), illus. in Bildteil.

$36 \quad$ F. A. Stoett. Nederlandse spreekwoorden en gezegden verklaard en vergeleken met die in het Frans, Duits en Engels. (9th edn., rev. and enl.; Zutphen 1974), no. 196. The English expression 'once in a blue moon' to indicate that something only occurs occasionally, is consistent with this: https://dictionary.cambridge.org/dictionary/english/once-in-a -blue-moon, last accessed 21 June 2021. An additional meaning that fits well with a rare phenomenon is that of the blue moon as a reference to a second full moon in a calendar month. This only occurs once every 2.7 years. Thanks to Rob Scheller for his suggestions on the meaning of the colour of the moon. 
helplessly to be overtaken by fate, but intervene by choosing and acting wisely at the right time.

The way in which the Master of Evert Zoudenbalch portrayed the personification of Luna is not at all consistent with the usual visual tradition of Luna in a two-horse chariot. The origin of the iconography for this unique Luna miniature is unknown. The Zoudenbalch Master may have used a compilation of entirely different sources of inspiration, such as a blue-coloured moon with a face, which he could have enlarged to function as a backdrop for Occasio-Fortuna and her wheel, who in turn deviates from the usual way of depicting her as the blindfolded Lady Fortune turning the wheel.

Mercury is depicted as a rich merchant or banker with a long beard seated behind a lectern with books, holding a money pouch in one hand and counting out money with the other. The open door of the cupboard in his lectern reveals books and writing utensils. He is wearing a long, fur-trimmed cloak and a red chaperon on his head, which also has a fur trim. He is set against the background of a large golden star (Fig. 3). The Mercury, after whom this planet is named, is the god of commerce and the messenger of the gods. The reference to trade is clearly present in the coins, the money pouch and the cash books in which the merchant keeps a record of his income and expenses. Depictions of Mercury with references to trade are not found in the Fendulus and Scotus manuscripts, nor in the Italian frescoes, but do appear in manuscripts and block books that originated in an urban context in the German countries in the first half of the fifteenth century. Equipped with a money bag and his winged shoes and caduceus (courier's staff) from ancient iconography, he appears naked with a star in front of his groin in a woodcut in the Planetary Poems of c. $1430 .{ }^{37}$ In the mid-fifteenth century Passau Calendar, Mercury, dressed in a fur-lined cloak similar to the clothing in the Wolfenbüttel miniature, is standing above his planet children. ${ }^{38}$ Seated behind a lectern on which there are coins and holding a money bag in hand, he is part of a Cosmic Man who is included in a German Speculum Humanae Salvationis of c. $1430 .^{39}$ The Zoudenbalch Master could have been inspired by such a representation for his own planet Mercury as a merchant.

37 Schweinfurt, Bibliothek Otto Schäfer. Blume, op. cit. (n. 8), Figs. 184-55.

38 Kassel, Universitätsbibliothek, Ms astron. 1, f. 66r. https://orka.bibliothek.uni-kassel.de/ viewer/image/1300793634809/133/, last accessed 21 June 2021.

39 Copenhagen, Det Kongelige Bibliotek, GKs $79,2^{0}$, f. 8r. See also I. Meekes, 'Onder invloed van Mercurius', in: Van Leerdam, op. cit. (n. 27), pp. 39-45, Fig. 4.6 and http://www5 .kb.dk/permalink/2006/manus/218/eng/8+recto/?var=, last accessed 21 June 2021. 


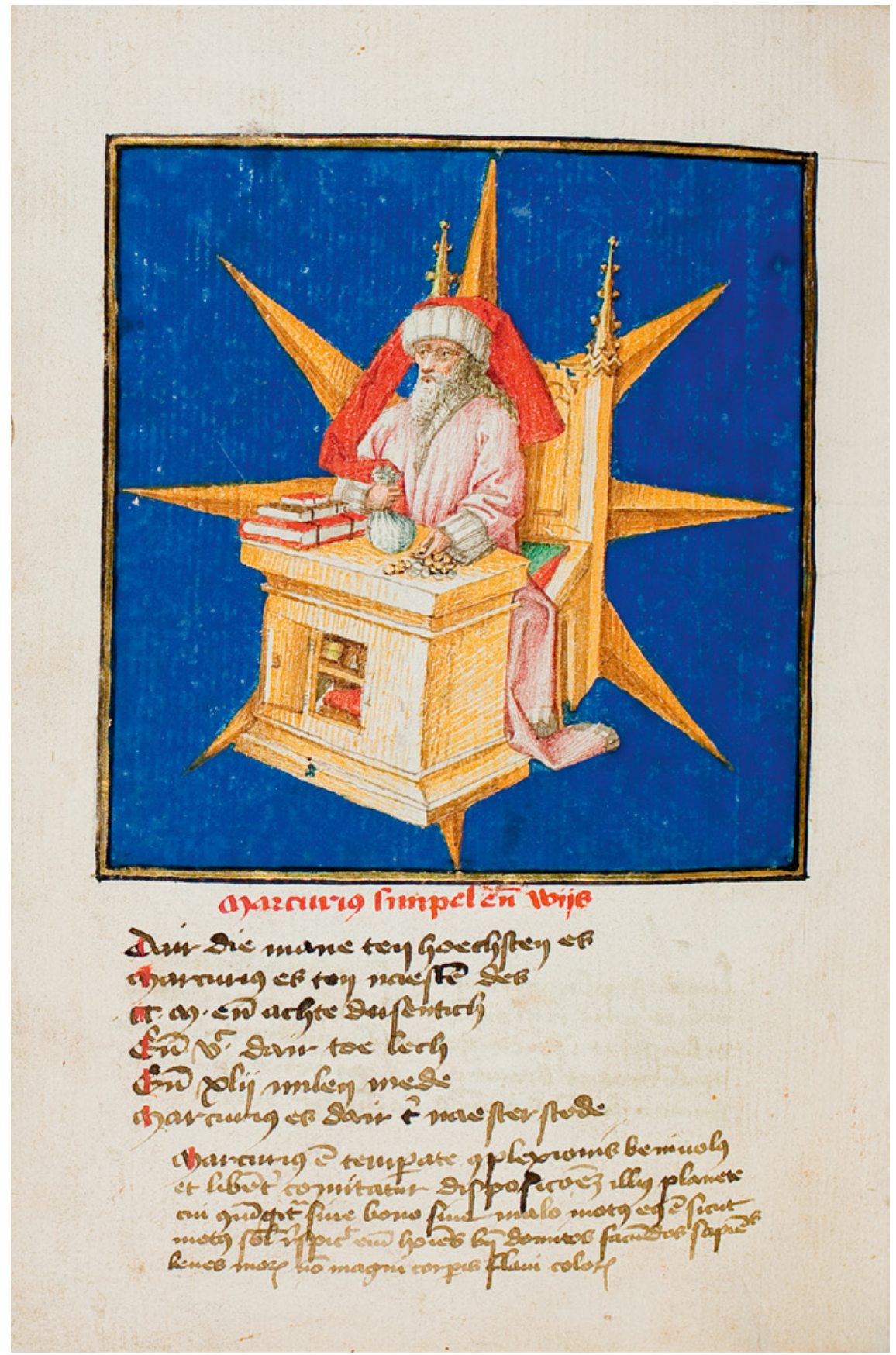

FIgURE 3 Master of Evert Zoudenbalch. Mercury. Wolfenbüttel, Herzog August Bibliothek, Cod. Guelf. 18.2.Aug.qu., f. 123v

(C): HeRzog AUgustbibliotheK, WOLFENBÜtTEL 


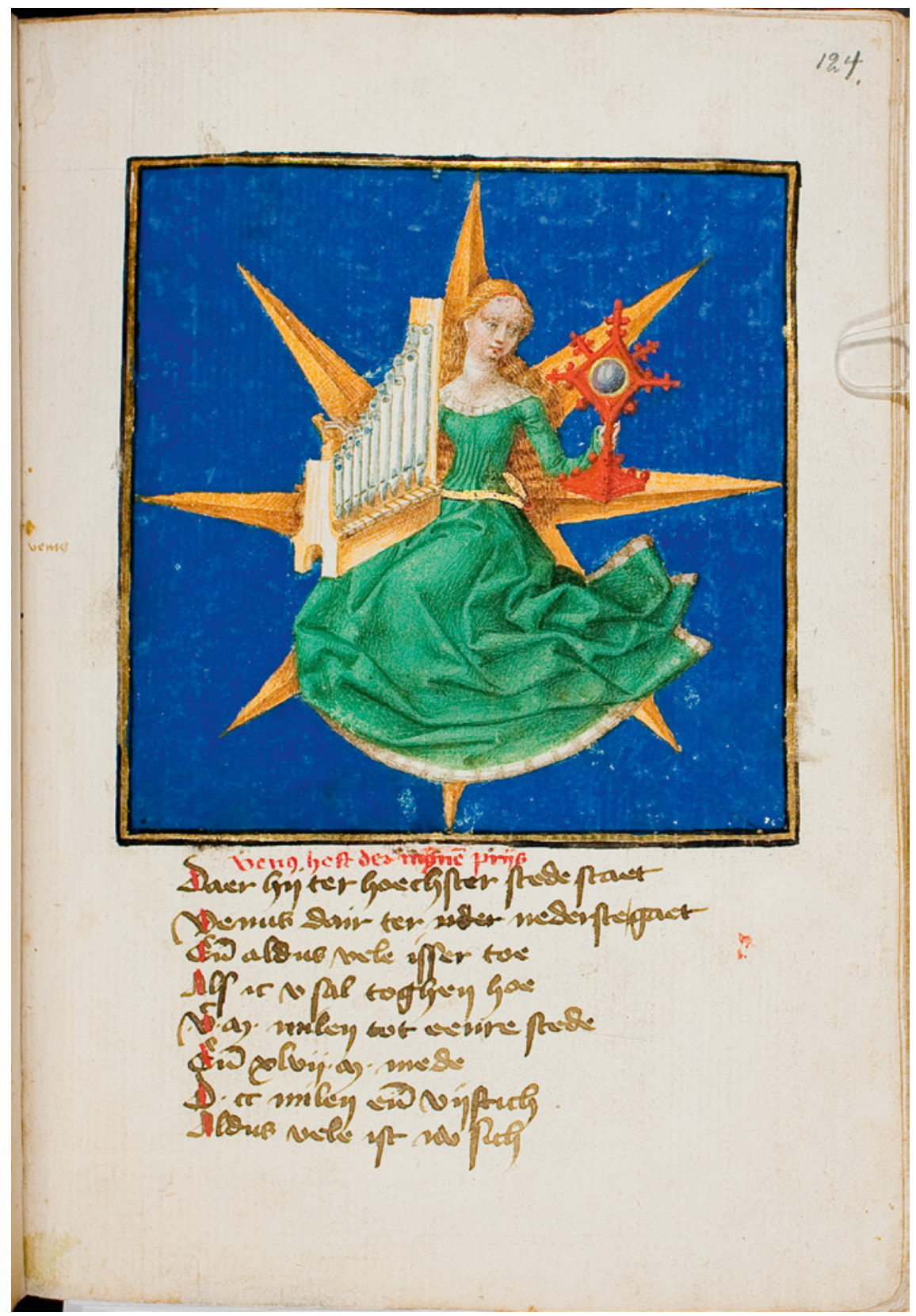

FIGURE 4 Master of Evert Zoudenbalch. Venus. Wolfenbüttel, Herzog August Bibliothek, Cod. Guelf. 18.2.Aug.qu., f. 124r

(C): HERZOG AUGUSTBIBLIOTHEK, WOLFENBÜTTEL 


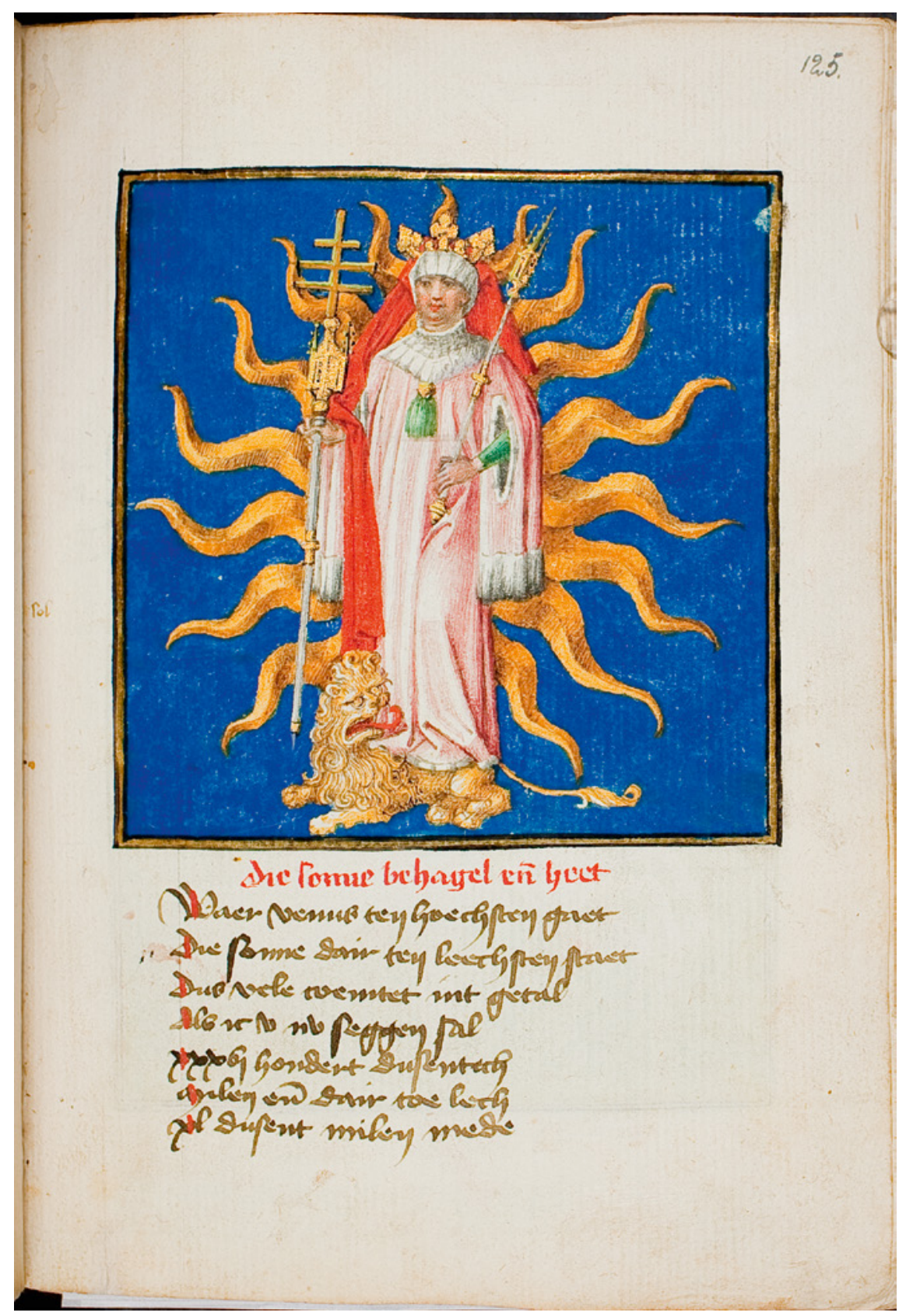

FIGURE 5 Master of Evert Zoudenbalch. Sol. Wolfenbüttel, Herzog August Bibliothek, Cod. Guelf. 18.2.Aug.qu., f. 125r

(C): HeRzog AugustbibliotheK, WOLFENBÜtTEL 
Venus, named after the goddess of love, is a beautiful young woman with long blonde hair, holding a small organ in her right hand and a mirror in the left. The way she holds the organ is a bit strange, for it is usually played with the right hand, but instead she is holding the bellows on the back with her right hand. ${ }^{40}$ She is sitting against the background of a large golden star (Fig. 4). The mirror is a very common attribute, and is often associated with the astrological Venus. ${ }^{41}$ There is no immediate explanation for the organ, but Venus is often depicted with musical instruments, for example in the Fendulus manuscripts in London and New York, where she plays the psalterium, a stringed instrument from classical times, and two fiddles can be seen next to her throne. ${ }^{42}$ She is seated in a way that is very reminiscent of the virgins sitting on the ground in Virgo inter Virgines scenes in panel painting. ${ }^{43}$ A seated Virgo with a mirror is depicted in a similar way in the calendar of a German Speculum Humanae Salvationis from c. $143{ }^{\circ} .{ }^{44}$ In view of these representations, in which the figures are in comparable postures, it is quite conceivable that the Master of Evert Zoudenbalch derived his composition of Venus as an elegant seated young woman with long blonde hair and a mirror from such a depiction.

Sol, the sun god, is a richly dressed man with a crown on his red fur-trimmed chaperon. He wears a long, fur-lined robe and holds in his hands a papal cross staff and a sceptre, symbols of ecclesiastical and secular authority. He is standing on a lion (Fig. 5). Unlike the other planets, he is not placed against a large golden star, but is surrounded by a flaming golden sun, comparable to the

40 Depictions of organs played by angels or St Cecilia are often found in fifteenth-century panel paintings.

41 G. de Tervarent. Attributs et symboles dans l'art profane, 1450-160o. Dictionaire d'un langage perdu, (Genève 1958), s.v. 'miroir', and G. F. Hartlaub, Zauber des Spiegels. Geschichte und Bedeutung des Spiegels in der Kunst (Munich 1951), Fig. 15o. In the frescoes in the Palazzo della Ragione in Padua she stands naked in the sign of Libra with a mirror in her hand, as well as in Modena, Biblioteca Estense, Ms 697, ff. 3v and 6v (Blume, op. cit. (n. 8), Figs. 117-18). She can be seen seated with a mirror in the church of the Eremitani, and in a capital on the south-west corner of the Palazzo Ducale in Venice from 1340-55 (Blume, op. cit. (n. 8), Pls. 25 and Fig. 102).

London, British Library, MS Sloane 3983, f. 42v: http://www.bl.uk/manuscripts/Viewer. aspx?ref=sloane_ms_3983, and New York, The Morgan Library \& Museum, M.758, f. 45v: http://ica.themorgan.org/manuscript/page/68/144038, last accessed 21 June 2021.

43 For instance the position of St Agnes in the panel by the Master of the St Lucy Legend in Brussels, Koninklijke Musea voor Schone Kunsten: https://www.fine-arts-museum.be/ $\mathrm{nl} /$ de-collectie/meester-van-de-lucialegende-virgo-inter-virgines-de-maagd-onder-de -maagden, last accessed 21 June 2021.

44 Copenhagen, Det Kongelige Biblioteket, GKS 79,2 ${ }^{0}$, f. 4v: http://www5.kb.dk/permalink /2006/manus/218/eng/4+verso/?var=, last accessed 21 June 2021. 
sun in depictions of Maria in sole. 45 The way Sol is represented does not fit in the tradition of the Fendulus and Scotus manuscripts, where this planet is depicted as enthroned or in a four-in-hand. The ruler symbols in the miniature in Wolfenbüttel are unusual, as is the fact that he is standing on the lion, which is not only his astrological house, but also the symbol of strength. ${ }^{46}$ This may be a reference to power and domination, fitting in with the ruler symbols. However, no parallels have been found for a representation of Sol standing on a lion. The Sol in Wolfenbüttel does, however, share a papal attribute with Guariento's Sol in Padua, who wears a papal tiara. ${ }^{47}$

As the god of war, Mars has the appearance of a warlike knight on horseback. He has a drawn sword in one hand, a shield in the other, and a flaming helmet on his head. A fire can also be seen on the flank of his horse. Like most planets, he is set against the background of a golden star (Fig. 6). His presentation bears no resemblance to the illustrations of the Fendulus and Scotus manuscripts, in which he is shown in armour, but not as a knight on horseback. This is, however, how Mars is depicted in the frescoes in the Palazzo della Ragione in Padua and in an unfinished miniature, which is bound in a Troy manuscript in Chantilly together with two other (also partly unfinished) renderings of planets. ${ }^{48}$ Two manuscripts in Modena and Oxford based on the frescoes of Guariento also show Mars as a knight on horseback. ${ }^{49}$ There are no such representations of Mars in the German Scotus tradition. However, in order to depict a knight on horseback, the Zoudenbalch Master need not necessarily have relied on an astrological manuscript as an example, since knights on horseback also appear as illustrations in other textual genres. In the German

45 Cf. Liège, Bibliothèque de l'Université, Ms Wittert 13, f. $13 \mathrm{v}$.

46 The signs of the zodiac are considered to be the houses of the planets, and mark the moment when the planet in question has special power. The planets known in the Middle Ages each have two houses ('Domus' or 'Domicilium'), with the exception of Sol and Luna, which only have one. In addition, the term 'houses' is also used for the twelve places ('Loci'), which refer to the different conditions of the life of man, like love, death, wealth, etc. Blume, op. cit. (n. 8), p. 6 and p. 235, n. $5^{-8}$. Whether the lion should really be understood as a reference to the constellation of Sol is not clear, as the signs of the zodiac are missing at the other planets.

47 Blume, op. cit. (n. 8), Pl. 26.

48 Chantilly, Musée Condé, Ms 754, f. 2v (Blume, op. cit. (n. 8), Fig. 80) and https://portail .biblissima.fr/fr/ark:/43093/mdata459aod2ffgdeceg64472a3b243a8167861b4a83a, last accessed 21 June 2021.

49 Modena, Biblioteca Estense, Ms lat. 697, f. gr: https://edl.beniculturali.it/beu/850o10962, and Oxford, Bodleian Library, Ms Canon Misc. 554, f. 173r: https://digital.bodleian .ox.ac.uk/shelfmarks.html, scroll to Bodleian Library Ms Canon. Misc. 554, last accessed 21 June 2021. 


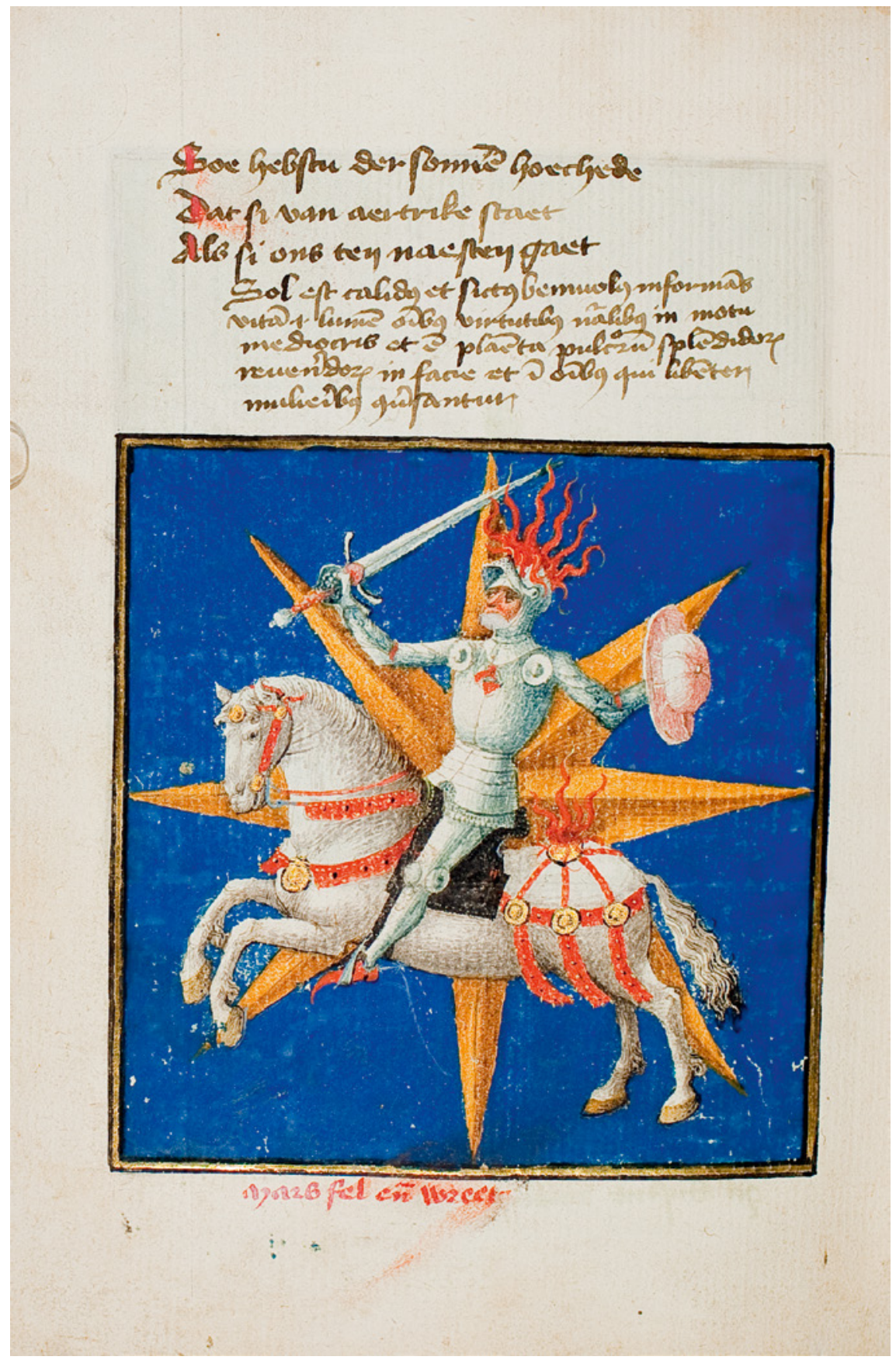

FIGURE 6 Master of Evert Zoudenbalch. Mars. Wolfenbüttel, Herzog August Bibliothek, Cod. Guelf. 18.2.Aug.qu., f. 125v

(C): HERZOG AUGUSTBIBLIOTHEK, WOLFENBÜTTEL 
Speculum Humanae Salvationis mentioned above, a rider appears twice on a galloping horse. ${ }^{50}$ Two depictions of a knight in the slightly later manuscript Dat Scaecspel, an adaptation of Jacobus de Cessolis's Ludus Scaccorum, in which representatives of different social classes are shown, make it clear that examples from non-astrological manuscripts are also possible. ${ }^{51}$ No parallels have been found for the flaming helmet or the fire on the horse's caparison, but the standing Mars in the above-mentioned Basel Planet block-book has a fire at shoulder height, which is undoubtedly a reference to the actions of his incendiary planet children, who are represented on the facing leaf. ${ }^{52}$

Jupiter is a youthful man in sumptuous clothing. His fur-trimmed tunic extends to below the knee, with a tippet and like Sol he has a crown on his furtrimmed chaperon. He is playing the harp against the background of a golden star (Fig. 7). This way of depicting Jupiter with a harp as attribute is in no way connected with the representations in astrological manuscripts, nor is it consistent with the frescoes in Padua. The Zoudenbalch Master's miniature is particularly reminiscent of David playing the harp in the Vienna Bible, who also wears similar clothes and holds his hands in the same way, but is presented in a different position..$^{53}$ There is no explanation for the harp as an attribute of Jupiter. The only planet depicted with a harp is Sol in illuminated manuscripts of Christine de Pizan's Epistre d'Othéa, so it does not seem entirely impossible that the Master of Evert Zoudenbalch has transposed the attributes of Sol and Jupiter. ${ }^{54}$

$5^{\circ}$ Copenhagen, Det Kongelige Bibliotek, GKs 79, $2^{0}$, f. $45 \mathrm{v}$ (Saul) and f. $93 \mathrm{r}$ (Moses): http:// www5.kb.dk/permalink/2006/manus/218/eng/45+verso/?var= and http://www5.kb.dk/ permalink/2006/manus/218/eng/93+recto/?var=1, last accessed 21 June 2021.

51 London, British Library, Ms Add.10.29o, f. 183r and f. 197r: http://www.bl.uk/manuscripts/ Viewer.aspx?ref=add_ms_1029o_fsoorr, last accessed 21 June 2021. With thanks to Anne Korteweg for the reference.

$5^{2}$ Blume, op. cit. (n. 8), Fig. 178-9.

53 Vienna, Österreichische Nationalbibliothek, Cod. 2771, f. 167v. Cf. O. Pächt-U. Jenni. Holländische Schule (Vienna 1975), Fig. 94.

54 For instance, The Hague, Royal Library, MS 74 G 27, f. 13v: http://manuscripts.kb.nl/zoom/ BYVANCKB\%3Amimi_74g27\%3Ao13v_min, last accessed 21 June 2021; Paris, Bibliothèque Nationale, Ms fr. 6o6, f. 7r. The renderings in the Epistre d'Othéa are influenced by the Ovide Moralisé, to which Christine de Pizan also refers. S. Hindman, Christine de Pizan's "Epistre d'Othéa". Painting and Politics at the Court of Charles VI (Toronto 1986), p. 78 and Fig. 13; M. Meiss, French Painting in the Time of Jean de Berry. The Limbourg Brothers and their Contemporaries (London/New York 1974), vol. I, p. 24. 


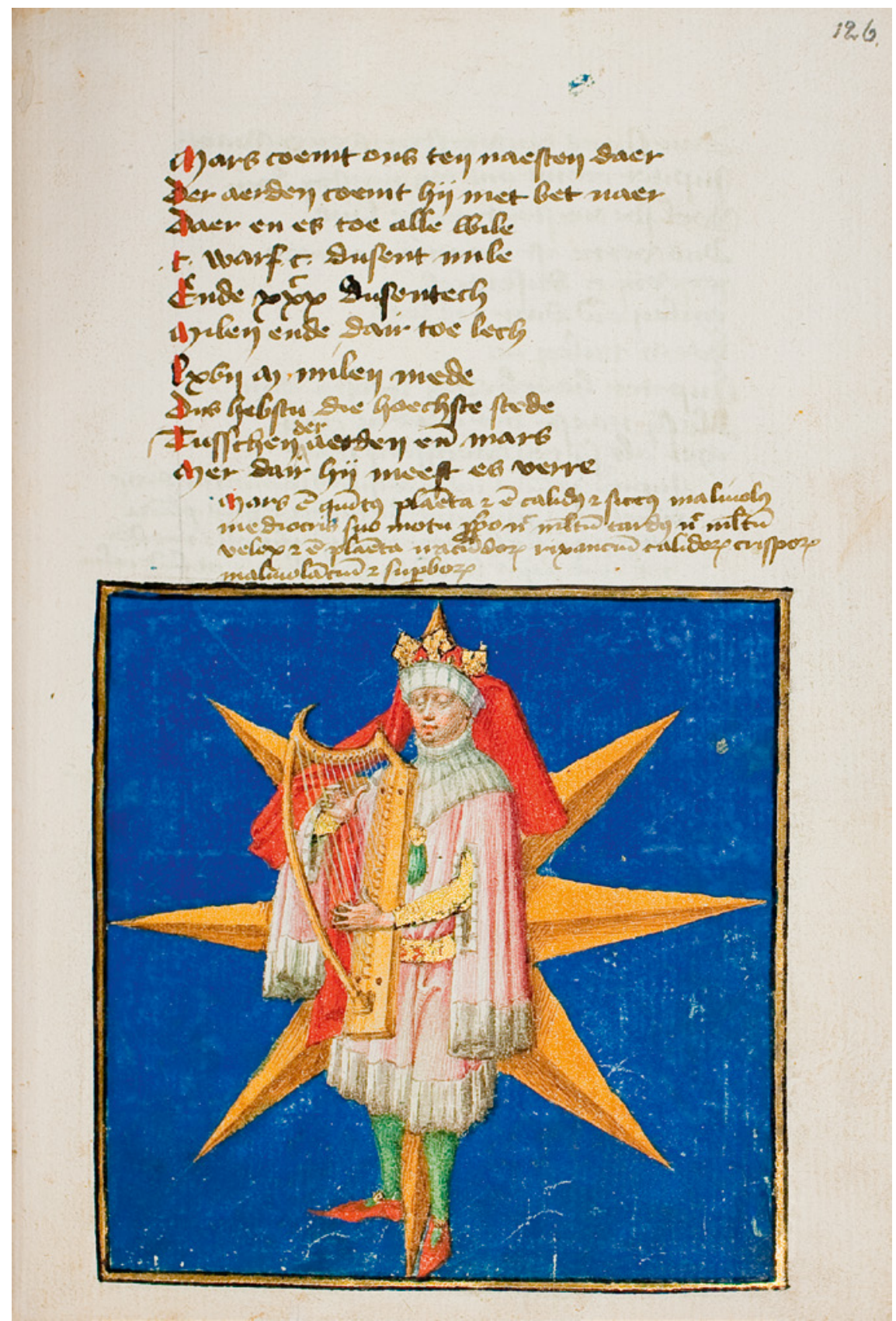

FIGURE 7 Master of Evert Zoudenbalch.Jupiter. Wolfenbüttel, Herzog August Bibliothek, Cod. Guelf. 18.2.Aug.qu., f. 126r

(C): HeRZog AUgUStBibliotheK, WOLFENBÜtTEL 


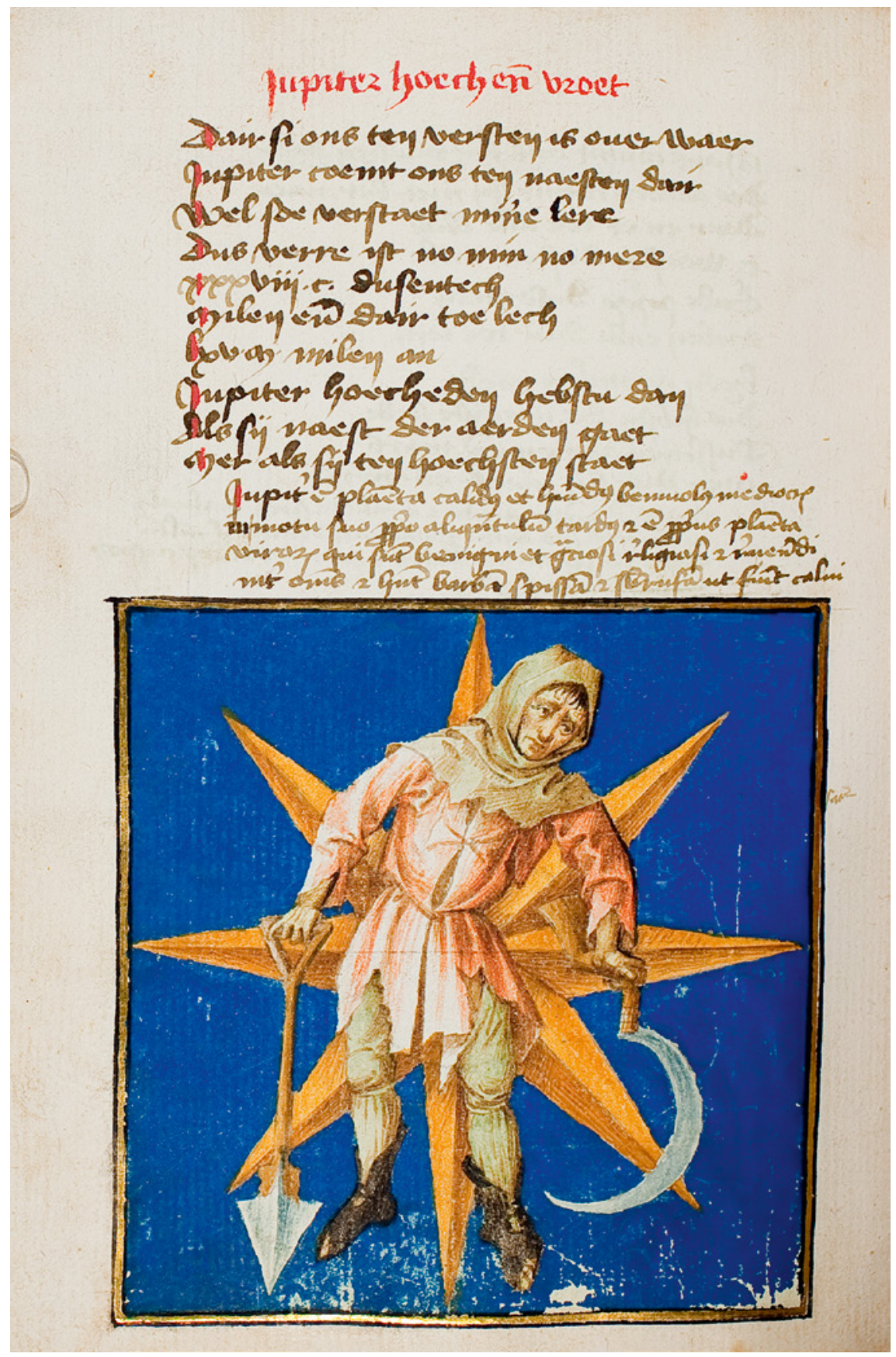

FIGURE 8 Master of Evert Zoudenbalch. Saturn. Wolfenbüttel, Herzog August Bibliothek, Cod. Guelf. 18.2.Aug.qu., f. 126v

(C): HERZOG AUGUSTBIBLIOTHEK, WOLFENBÜTTEL 
Named after the god of agriculture, Saturn is depicted as a scruffy man with frayed clothes placed in front of a large golden star. His attributes are a spade to till the ground and a sickle to harvest the sown wheat (Fig. 8). These are the traditional attributes of Saturn, and also appear in the manuscripts of Fendulus and Scotus and in the frescoes in Padua. In the German Scotus tradition, he also has a sickle, often in combination with a crutch, because he is limping. ${ }^{55}$ However, it is questionable whether the Zoudenbalch Master did not use any other examples than illustrations in astrological manuscripts for his depiction of a farmer. Thus, in the manuscript of Dat Scaecspel, mentioned in connection with Mars, there is a farmer with so many similarities to Saturn in the Natuurkunde van het Geheelal that one can well imagine that the Master of Evert Zoudenbalch was familiar with scenes of this kind. ${ }^{56}$

In conclusion, the Master of Evert Zoudenbalch's representations of the planets do not arise from their presentation in thirteenth-century astrological manuscripts, which spread from Italy to the north. However, the eight-pointed stars in the backgrounds of Mercury, Venus, Mars, Jupiter and Saturn must have been borrowed from Italy, where they first appear in the frescoes in Padua and then in the Italian manuscripts, for which Guariento's frescoes were the source of inspiration. ${ }^{57}$ As regards the iconography of Mercury as a merchant or banker, it is first encountered in the German-speaking Scotus tradition of the first half of the fifteenth century in the form of a standing Mercury with a money bag in hand. It appears from the comparisons cited for the individual planets that some compositions can be found in non-astrological sources that may have inspired the Zoudenbalch Master. Since illuminators usually worked after examples, especially for unusual depictions, it is hard to imagine that the personifications of the planets should be regarded entirely as inventions by the Master of Evert Zoudenbalch. He probably had access to models, possibly a manuscript with comparable images or one or more model drawings. ${ }^{58}$ Until

55 See Blume, op. cit. (n. 8), Fig. 174.

56 London, British Library, Ms Add. 10.290, f. 202v: http://www.bl.uk/manuscripts/Viewer. aspx?ref=add_ms_1029o_fsoorr, last accessed 21 June 2021.

57 Blume, op. cit. (n. 8), Pls. 16-21, 23-34, Figs. 70-77 and 109-14. Modena, Biblioteca Estense Universitaria, Ms lat. 697. Blume, op. cit. (n. 8), Figs. 117-20: https://edl.beniculturali.it/ beu/850010962 and Oxford. Ms Canon Misc. 554: https://digital.bodleian.ox.ac.uk/shelf marks.html, scroll to Bodleian Library Ms Canon. Misc. 554, last accessed 21 June 2021.

$5^{8}$ Model sheets have rarely been preserved. R. Scheller, 'Reizende voorstellingen', in: Ateliergeheimen. Over de werkplaats van de Nederlandse kunstenaar vanaf 1200 tot heden (Lochem/Amsterdam 2006), p. 107. Also R. W. Scheller, Exemplum. Model-Book Drawings and the Practice of Artistic Transmission in the Middle Ages (ca. 9oo-ca. 1470) (Amsterdam 1995). Mike Kestemont and Folgert Karsdorp have calculated that fewer than half of all medieval knightly novels have survived: M. Kestemont and F. Karsdorp, 'Het Atlantis van 
such traces are found, the question of the origin of the special iconography of the planets cannot be answered, nor that of a possible confusion of the attributes of Sol and Jupiter.

\section{The Zodiac in the Natuurkunde van het geheelal}

Like the planets, the signs of the zodiac (ff. 139r-51v) in the Natuurkunde, are in the form of miniatures, albeit slightly smaller than those of the planets. They are also one column wide, but only take up about a third of the writing surface. Like the planet miniatures they are set in a golden frame. The miniatures precede the text about the sign in question, which varies in length, with the result that the miniatures do not have a fixed place on the page. In one case, the scribe left a little too much space above and especially below the Taurus miniature (f. 141r). There was also not enough space for Leo (f. 144r), where the depiction takes up much of the lower margin.

The signs begin with Aries or Ram (f. 139v), in accordance with the start of the astrological year, and always precede the text passages in which they are discussed in relation to the ever-changing position of the sun. The discussion of the signs of the zodiac is followed by a few more lines in Middle Dutch and Latin containing miscellaneous information, such as favourable moments for medical treatments. ${ }^{59}$ That information is not included in the other editions of the Natuurkunde van het Geheelal.

The signs of the zodiac are clustered by the colour of their backgrounds: the water signs Pisces, Cancer and Scorpio have a light blue background with waves, the fire signs Aries, Leo and Sagittarius a red one, the earth signs Taurus, Virgo and Capricornus a grey one and the air signs Gemini, Libra and Aquarius a blue. ${ }^{60}$ Most of the signs are shown turned to the left. The Master of Evert Zoudenbalch painted the signs of the zodiac in much the same way in his miniature of the universe in the Vienna Bible, although there he painted Gemini seated instead of fighting, probably because of the limited space in the sphere

de Middelnederlandse ridderepiek. Een schatting van het tekstverlies met methodes uit de ecodiversiteit', Spiegel der Letteren, 3 (2019), pp. 271-9o. This will be no different for other genres.

The text passages in the manuscript in Wolfenbüttel are much longer than for instance those in Uppsala, where an average of ten lines of text is devoted to each sign of the zodiac.

6o The signs of the zodiac are divided among the four elements water, fire, air and earth. 
of the fixed stars. ${ }^{61}$ Here too, the characters, with the exception of Virgo, are shown turned to the left and grouped by the background colours.

Most of the animal signs do not deviate from the usual iconography and are limited to minor variations in pose, such as those that regularly occur between around 1200 and $1500 .{ }^{62}$ For example, Aries is lying down with its head turned back; Capricornus is also recumbent, while Leo is roaring and standing with its tail twisted around its body. Taurus is shown half-length in the way in which it is almost always depicted in astrological manuscripts, even as early as the Carolingian manuscript of the Aratea in Leiden. ${ }^{63}$ Signs such as Cancer, Scorpio and Libra depict a stylized lobster, scorpion and scales. ${ }^{64}$ Of the animal Signs, Pisces is quite playful. The two fish are frolicking against a bluish, wavy background that suggests water, while they are usually shown swimming in opposite directions and connected by a band or rope.

The personified signs are more original. Aquarius (Fig. 9), his head turned to the left but in a crouching pose to the right, is seen from behind, with a jug clamped under his right arm from which water flows, and is holding a cloth in his left hand. Gemini (Fig. 10) takes the form of two nude young men fighting, whereas it is usually represented by two boys with their arms around each other. Virgo (Fig. 11), a winged young woman who had been holding flowers or ears of corn since the thirteenth century, has been painted by the Master of Evert Zoudenbalch in profile with wings and a raised forefinger, whereas she is usually depicted en face. Sagittarius is proceeding at a gallop as he fires a bow, and has a fluttering band around its head. Both the crouching Aquarius and the winged Virgo in profile are seen from the back, as they are in a celestial map of 1435 in Vienna, which also shows Gemini in a pose that can be interpreted as fighting, and Sagittarius with an emphatically fluttering headband. ${ }^{65}$

61 The miniatures of Cancer, Scorpio, Aries and Pisces are attributed to an assistant by Henri Defoer in Marrow et al., op. cit. (n. 5), cat. no. 64, pp. 208-209. However, to me that seems difficult to determine in these non-figurative representations.

62 See the illustrations in Blume, op. cit. (n. 8).

63 Leiden,Universiteitsbibliotheek,Ms Voss.Lat.Q.79,f.24v.SeeR.Katzenstein-E.Savage-Smith, The Leiden Aratea. Ancient Constellations in a Medieval Manuscript (Malibu 1988), p. 24: https://www.staff.science.uu.nl/ gento113/hovo/downloads/the_leiden_aratea.pdf, last accessed 21 June 2021.

64 Sometimes the scales are held by a man or a woman.

65 Vienna, Österreichische Nationalbibliothek, Cod. 5515. Blume, op. cit. (n. 8), cat. no. 64 and Fig. 55o. I am grateful to Dieter Blume for the reference. 


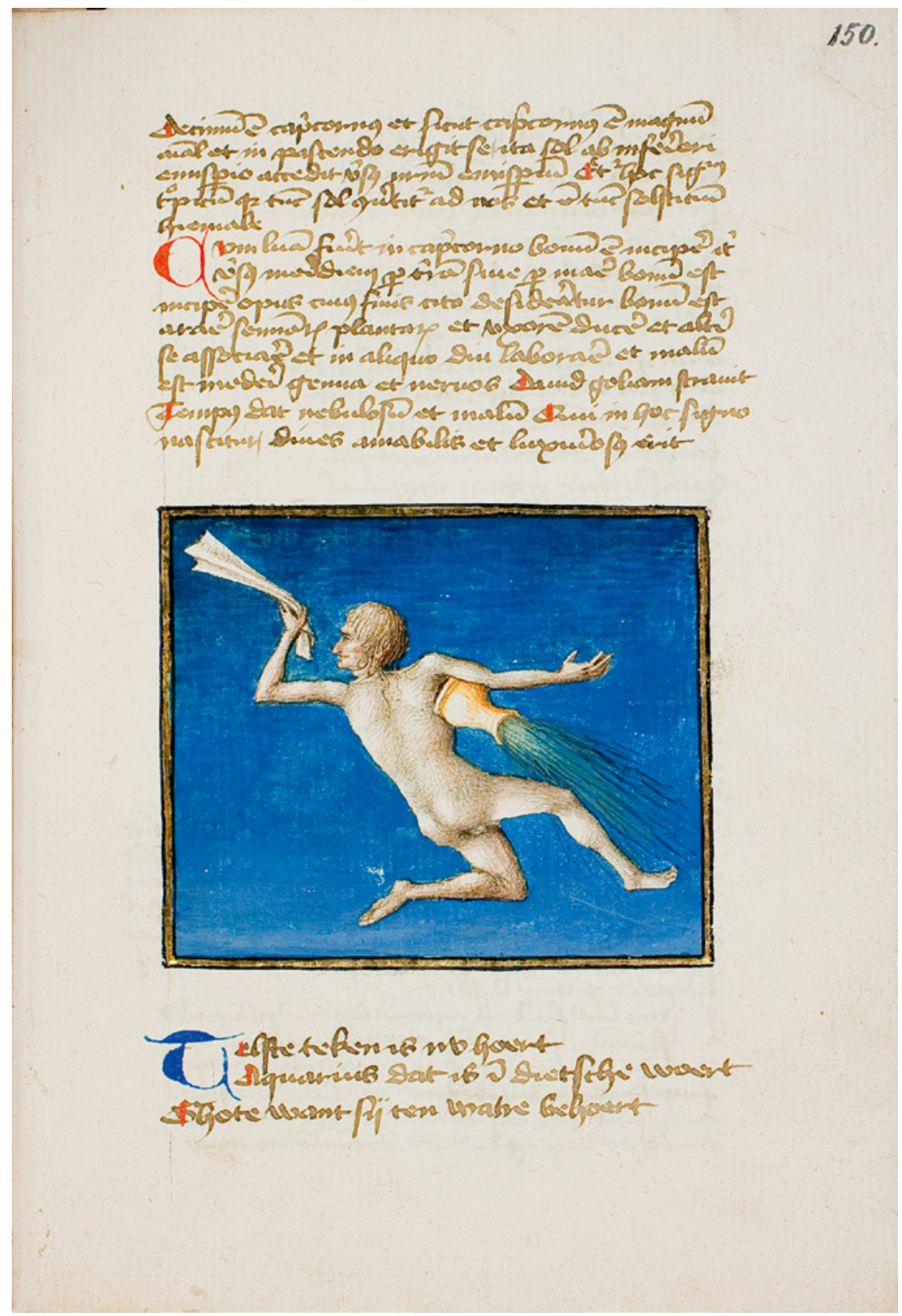

FIGURE 9 Master of Evert Zoudenbalch. Aquarius. Wolfenbüttel, Herzog August Bibliothek, Cod. Guelf. 18.2.Aug.qu., f. 15or

(C): HeRZog AUgUStbibliotheK, WOLFENBÜtTEL 


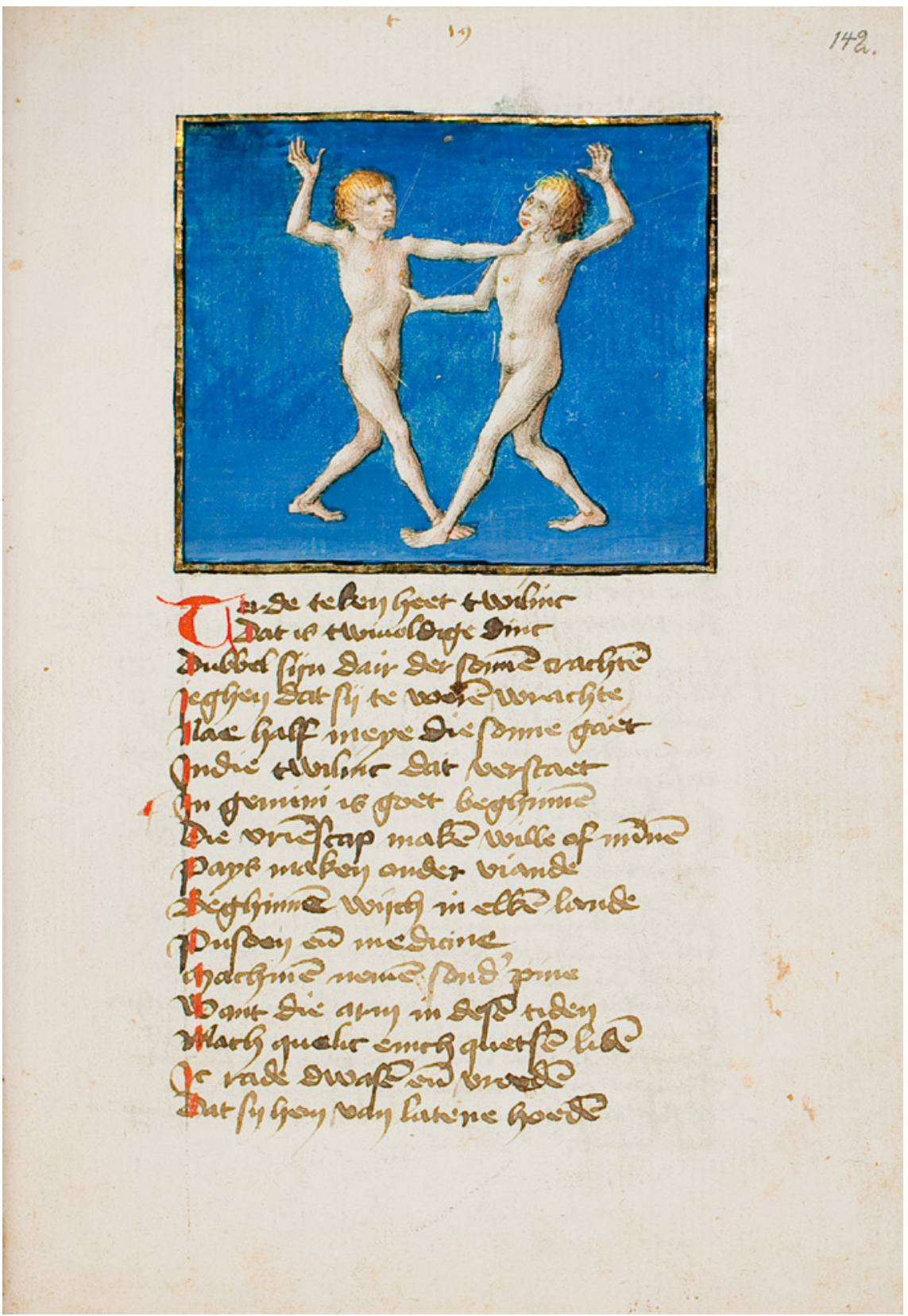

FIGURE 10 Master of Evert Zoudenbalch. Gemini. Wolfenbüttel, Herzog August Bibliothek, Cod. Guelf. 18.2.Aug.qu., f. 142r

(C): HERZOG AUGUSTBIBLIOTHEK, WOLFENBÜTTEL 


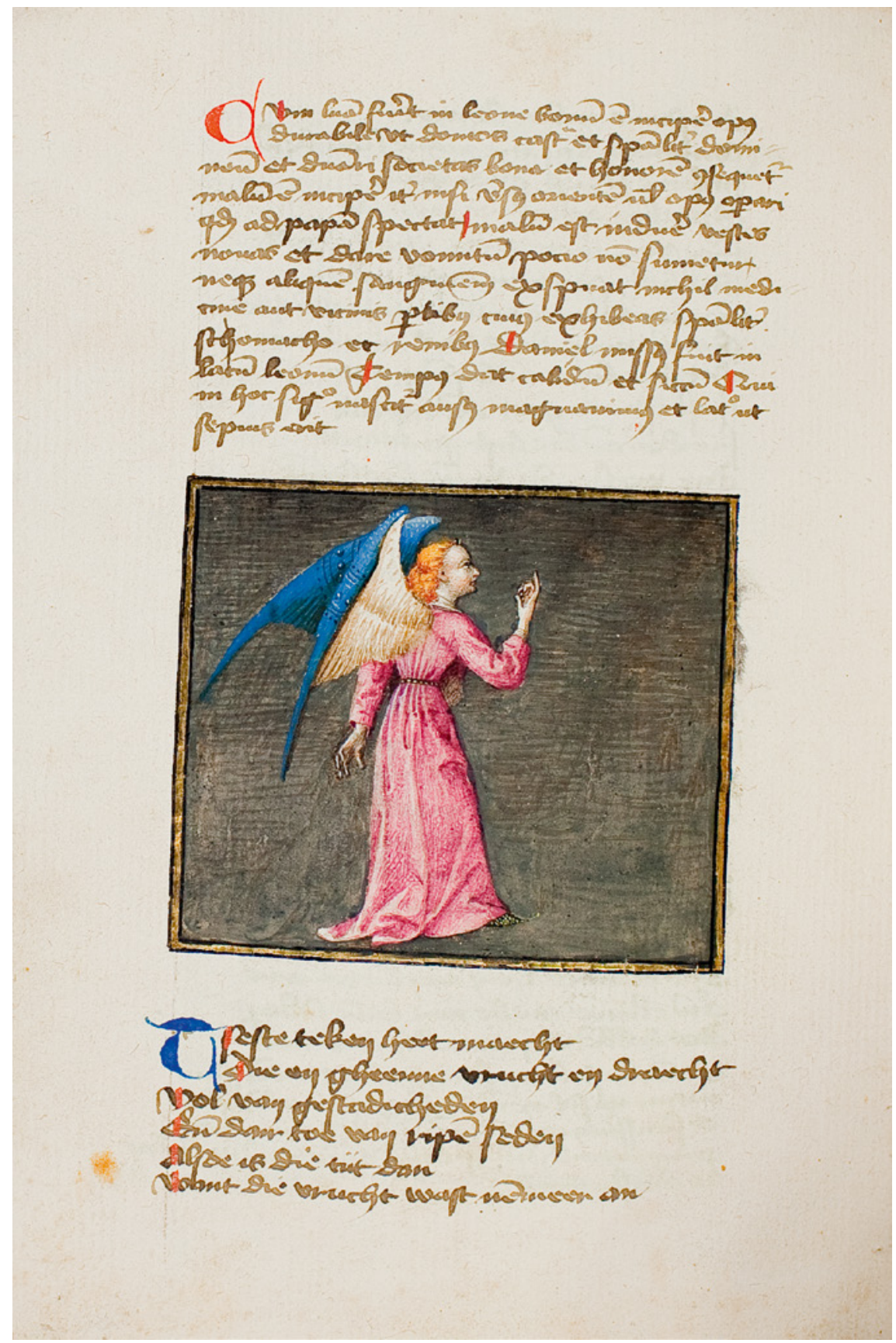

FIGURE 11 Master of Evert Zoudenbalch. Virgo. Wolfenbüttel, Herzog August Bibliothek, Cod. Guelf. 18.2.Aug.qu., f. 145

(C): HeRZog AUgUStBibliotheK, WOLFENBÜtTEL 
The Master of Evert Zoudenbalch must have had an astrological manuscript as a model for his signs of the zodiac, for the iconography of the signs in the Natuurkunde van het Geheelal is consistent with the manner of representation in such manuscripts, and some of the signs are very similar to those on the celestial map in Vienna, which was widely imitated and was the model for Dürer's Celestial Map.

\section{The Astronomical Illustrations}

The texts on the individual planets are preceded by an introduction dealing with more general matters concerning the planets (ff. $118 \mathrm{v}-122 \mathrm{v})$. These sections are decorated with various drawn or painted schematic representations, such as a drawing of the thirteen spheres of the universe, a painting of the way in which the moon receives light from the sun, and two schematic drawings of the houses of the planets. The miniatures of the planets and accompanying texts are followed by information about stars, comets and meteorological matters (ff. $127 \mathrm{r}-38 \mathrm{v}$ ). These texts feature painted representations of different kinds of stars and comets, lightning and rain, and the like. They are placed within small roundels between the texts and differ in size (Figs. 12, 13). Most of these types of schematic representation are painted in bright colours, only one of the schemes is drawn (see the Appendix for an overview of the representations). It is difficult to make out whether these illustrations are also by the Master of Evert Zoudenbalch.

\section{The Bloodletting Zodiac Man}

Included at the end of the phlebotomy instructions, which precede the Natuurkunde van het Geheelal, is a full-page coloured drawing of a seated bloodletting Zodiac Man with visible viscera (f. 11or). The names of the constellations are written on his body to indicate which parts they influence: the head (Aries), the neck (Taurus), the arms (Gemini), and so on. In addition, there are red lines that indicate the locations of the veins (Fig. 14). This drawing makes it clear that a medieval physician also needed knowledge of astrology, because he had to take the position of the stars into account when diagnosing and treating diseases. ${ }^{66}$ This is related to the medieval world view, in which it

66 On the relationship between medicine and astrology see E. Huizenga. Een nuttelike practijke van cirurgien. Geneeskunde en astrologie in het Middelnederlandse handschrift 


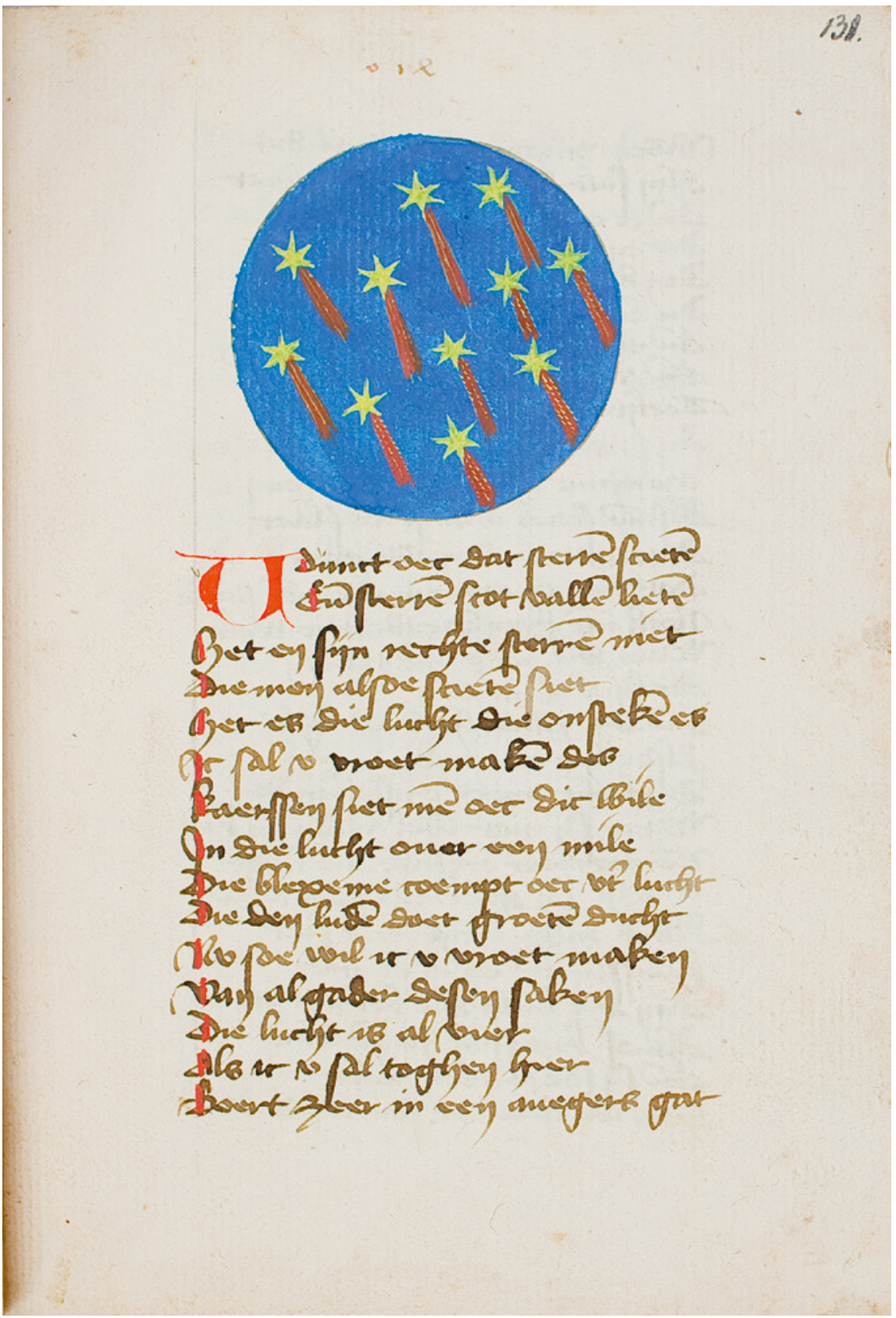

FIGURE 12 Comets. Wolfenbüttel, Herzog August Bibliothek, Cod. Guelf. 18.2.Aug.qu., f. 131r (C): HeRZOG AUGUSTBIBLIOTHEK, WOLFENBÜTTEL 


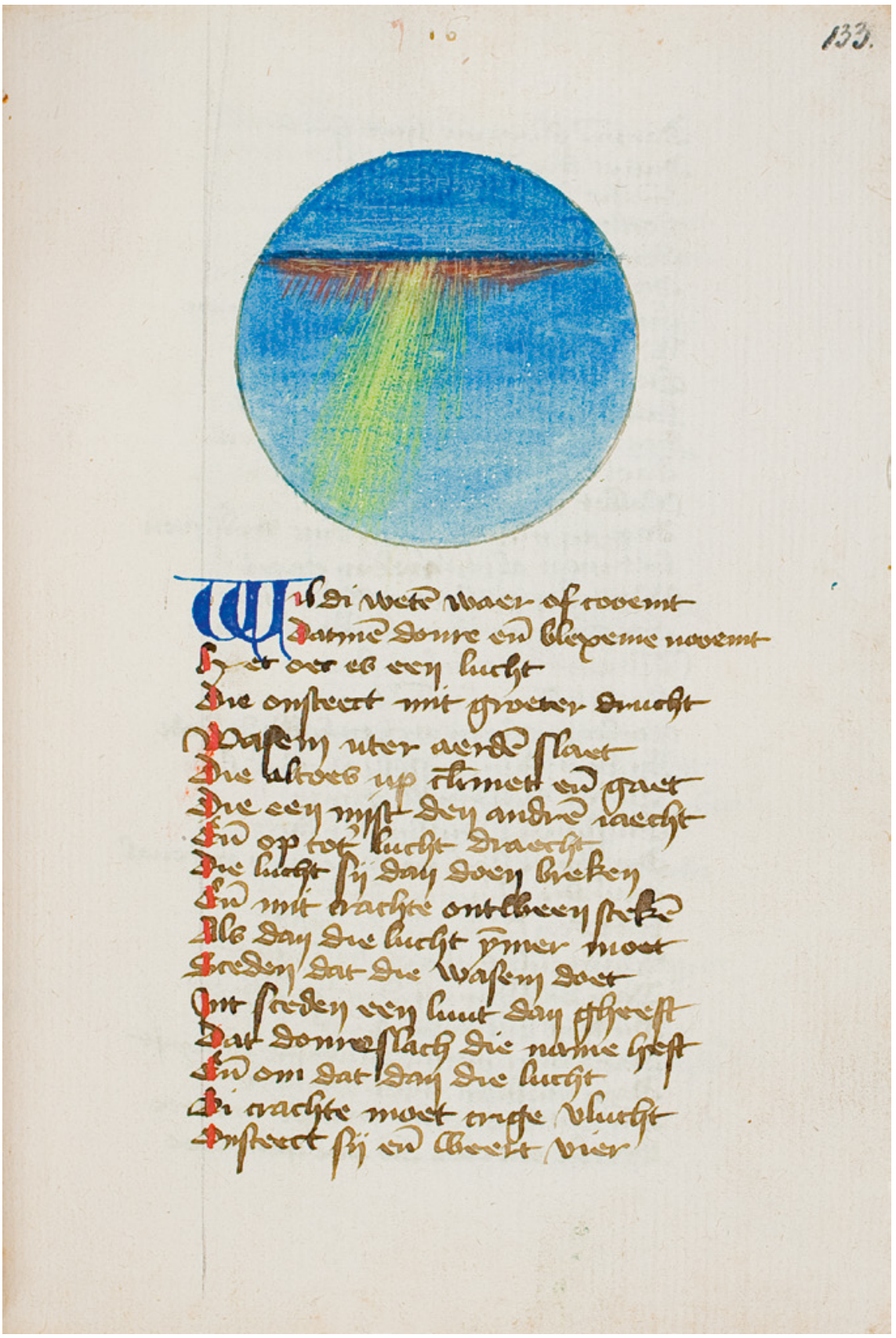

FIGURE 13 Flash of lightning. Wolfenbüttel, Herzog August Bibliothek, Cod. Guelf. 18.2.Aug. qu., f. $133 \mathrm{r}$ (C): HERZOG AUGUSTBIBLIOTHEK, WOLFENBÜTTEL 


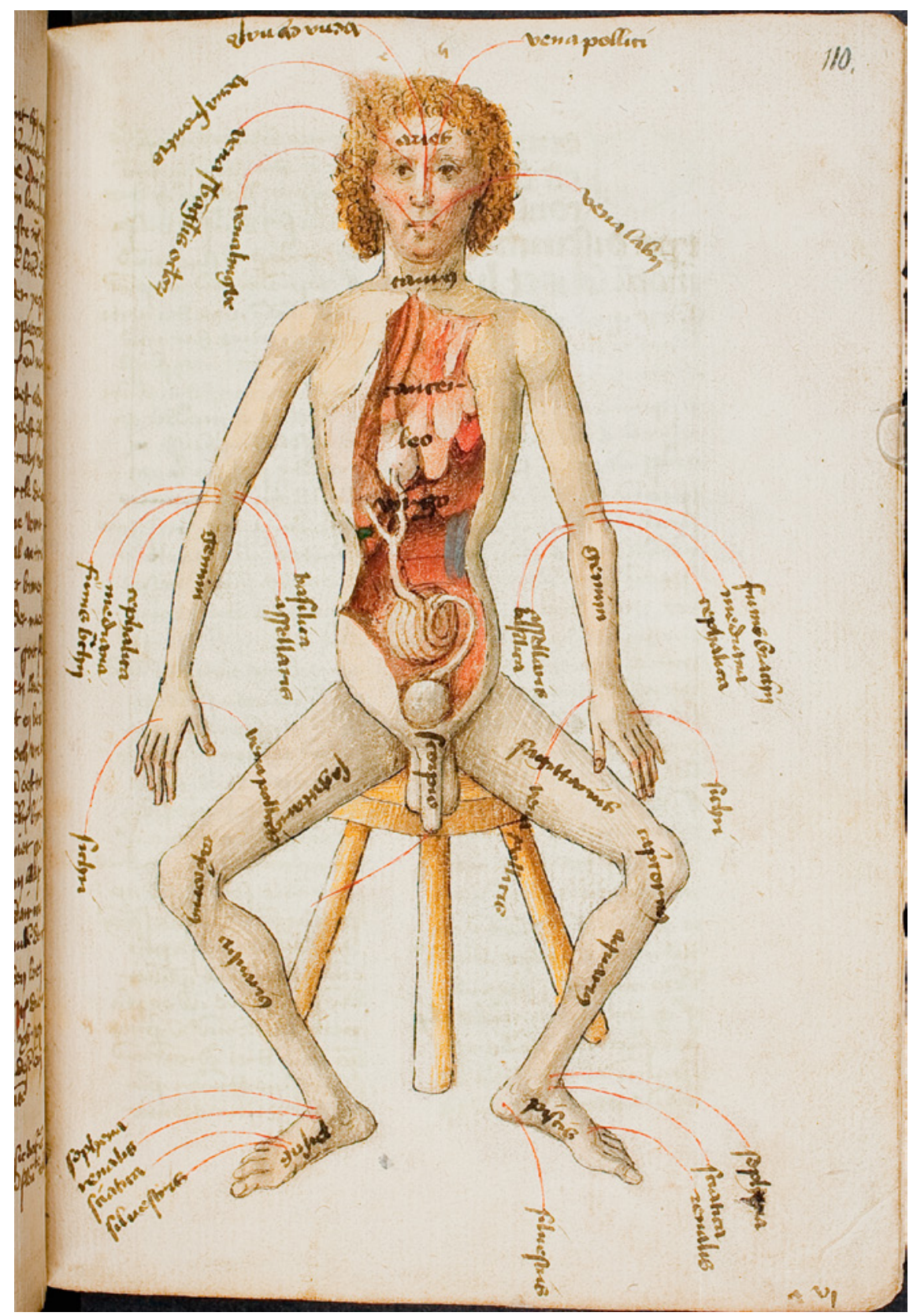

FIGURE 14 Bloodletting Zodiac Man. Wolfenbüttel, Herzog August Bibliothek, Cod. Guelf. 18.2.Aug.qu., f. 11or

(C): HERZOG AUGUSTBIBLIOTHEK, WOLFENBÜTTEL 
was assumed that man (microcosm) is a reflection of the world writ large, the universe (macrocosm). The origin of this idea can be traced back to Antiquity, when it was thought that the four humours or bodily fluids (blood, phlegm, yellow bile and black bile) determine human health. A person becomes ill when they are not in balance, and a quick way to restore that balance was by bloodletting. ${ }^{67}$

Representations of bloodletting Zodiac Men are common illustrations in medical writings. The representations are often limited to simple schematic drawings, around which the names of the veins and the diseases may or may not be indicated. ${ }^{68}$ Occasionally, as in the Wolfenbüttel manuscript of the Natuurkunde, one finds well-developed drawings or painted miniatures. The most famous example of a painted miniature is the aforementioned Zodiac Man in Jean de Berry's Très Riches Heures. ${ }^{69}$

The depiction of the Bloodletting Zodiac Man in the Wolfenbüttel manuscript is not by the Master of Evert Zoudenbalch. The thin contours of the figure, the design of the hair as tight curls and the way in which the figure is coloured, provide less plasticity than in the personifications of the planets and the figurative signs of the zodiac: Gemini, Aquarius and Virgo. This coloured drawing may have been made by an assistant.

\section{Who Was the Natuurkunde van het Geheelal Intended for?}

It is difficult to determine exactly for whom this book was intended. The patron left no traces in the manuscript, and no owners are known before it entered the collection of Duke August the Younger of Braunschweig-LüneburgWolfenbüttel (1579-1666) shortly after 1636. However, the owners of some of the Dutch Natuurkunde manuscripts are known. They were a pastor of a parish church, a noble family, a monastery, a doctor, and a Nijmegen merchant or a canon from that city. ${ }^{70}$ With the exception of the noble family's manuscript, all

Wenen, Österreichische Nationalbibliothek, 2818. (doctoral dissertation Rijksuniversiteit Groningen). (Hilversum 1997), pp. 22-26.

$67 \quad$ K. van 't Land, 'Het verloop van evenwicht. Mens en samenleving in Laat-middeleeuwse humoraaltheorieën', Gewina, 28 (2005), pp. 61-78.

68 K. Marcelis, De afbeelding van de aderlaat- en de zodiakman in astrologisch-medische handschriften van de $13^{\text {de }}$ en $14^{\text {de }}$ eeuw (Brussels 1986).

69 J. Longnon and R. Cazelles, De Très Riches Heures van Jean, Duc de Berry (Utrecht/Antwerp 1973), Fig. 14.

70 J. Reynaert, 'Wereldbeeld en astrologie in Middelnederlandse didactische literatuur (tot ca. 1400)', Nederlandse Letterkunde, 9 (2004), pp. 210-32. 
the Natuurkunde copies also contain medical texts. So the text must have been for someone of some intellectual capacity who was interested in astronomy and astrology, computistics and medicine. Reynaert speaks of an 'intellectual middle-class man', who had at least graduated from the Latin school. ${ }^{71}$ The inclusion of clauses in Latin in the Natuurkunde and the combination with Latin texts also point in this direction.

The Wolfenbüttel manuscript, which contains not only indications for phlebotomy, but also medical prescriptions, would have been very suitable for a physician, especially since the Natuurkunde manuscript in Uppsala notes that a good doctor ('fisiker') must have a knowledge of astrology in order to exercise his profession properly. ${ }^{72}$ It is difficult to determine which medical practitioner is meant by the term 'fisiker'. The doctores medicinae, who had studied at the university, were mainly concerned with 'internal medicine' and studied, among other things, the urine, faeces, saliva and sweat of their patients, who belonged to the highest circles of society. However, they also paid a lot of attention to the doctrine of the humores, since illness was the result of a lack of balance between the four bodily fluids. Unlike the doctores, a surgeon did not have a university education, but learned medicine in practice as a master's apprentice. He was mainly concerned with all possible external treatments, such as fractures and wounds, as he was forbidden to engage in 'internal medicine'. Phlebotomy was one of his main treatments. Surgeons could also be employed by the high nobility and clergy, but more often worked in a city as employees of the city council. ${ }^{73}$

Despite the information on natural phenomena, the text of the Natuurkunde van het Geheelal in Wolfenbüttel is mainly aimed at practical medical knowledge, in particular of phlebotomy. That is why a learned surgeon would seem to have been a suitable recipient of such a book. However, the inclusion of the miniatures with the personifications of the planets and the signs of the zodiac was not necessary, since, unlike the bloodletting Zodiac Man and the astronomical diagrams and tables, they have no practical function

71 Reynaert, art. cit. (n. 70), p. 213. Veltman concludes that the audience for astrological texts in composite manuscripts can be very varied. L. Veltman, 'Een breed spectrum tussen hemel en aarde. Astronomie in verzamelhandschriften', in: Artes in context. Opstellen over het handschriftelijk milieu van Middelnederlandse artesteksten, ed. O. S. H. Lie and R. Reynaert (Hilversum 2004), pp. 59-78, pp. 75-6.

72 In the margin of line 1242 in Uppsala one reads: 'Waer bi dat een recht fisiker emmer astronomie connen moet'. Jansen-Sieben, op. cit. (n. 2), vol. I, p. 36o. For the whole text on the 'fisiker' see lines 1242-86.

73 The barber-surgeon or barber, who mainly performed bloodletting and pulled teeth and molars, had no knowledge of Latin and was sometimes even illiterate. On the different medical practitioners in the Middle Ages see Huizenga, op. cit. (n. 66), pp. 221-73. 
whatsoever. That being said, the Latin phlebotomy text, in which lines of verse from the Regimen Sanitatis Salernitanum are quoted in such a mutilated way that they are occasionally incomprehensible, also makes it clear that the owner of the manuscript was not directly concerned with the practical directions for the bloodletting, but rather with the information about the days on which this should be done. ${ }^{74}$ The presence of the miniatures of the planets and the signs of the zodiac therefore points instead to a wealthy person from the Utrecht elite with an interest in astronomy, astrology and medicine, who wanted a relatively cheap paper book with fascinating texts, that was also beautifully illuminated with representations of the most important celestial bodies, which govern human life.

74 Thanks to Willem van Bentum for this information. He draws particular attention to f. $108 \mathrm{v}$. 


\section{Appendix}

Wolfenbüttel, Herzog August Bibliothek, Cod. Guelf. 18.2. Aug. $4^{0}$

Willem Walterzoon van Zierikzee, Descriptio de tota terra promissionis cum Iherusalem and other texts; Odericus de Pordenone, Sanctus Odericus de foroJulii oreundus est auctor sequencium

De Flebotomia, Computus in Latin and Dutch and De Natuurkunde van het Geheelal Utrecht, Master of Evert Zoudenbalch (illuminator), ca. 1465-1470

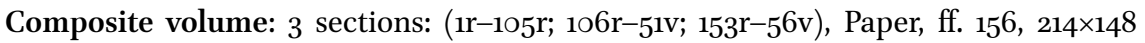
$\left(155^{\times} \times 93\right) \mathrm{mm}, 1$ column (1r-105r; 112r-56r) and 2 columns (106r-11v), 25-36 lines (ff. $1 \mathrm{r}-105 \mathrm{r}$ ) and 33-37 lines (ff. 106r-66r), littera cursive and littera hybrida (at least 3 hands). Latin (ff. 1r-112r; 152r-56r); Dutch and Latin (112v-51v). Binding: 17th-century vellum

Decoration: 7 half-page miniatures $(110 \times 110 \mathrm{~mm})$; 12 column miniatures $(75 \times 85 \mathrm{~mm})$; 16 miniatures $(30 / 70 \times 30 / 70 \mathrm{~mm}) ; 1$ full-page coloured drawing $(160 \times 110 \mathrm{~mm})$; 6 (coloured) drawings (50×100 $\mathrm{mm}) ; 2$ penwork initials with pen-flourishes in Utrecht style ('Crown and Dragon') (ff. 106r and 11ov)

Provenance: August der Jüngere, Herzog von Braunschweig-Lüneburg-Wolfenbüttel (1579-1666) (acquired shortly after 1636)

Digital resources: http://diglib.hab.e/?db=mss\&list=ms\&id=18-2-aug-4f\&lang=en (with description (Heinemann - no. 3133) and literature)

\begin{tabular}{llll}
\hline Quires & Folios & Contents & Decoration \\
\hline I $^{12-1(\text { before 1) }}$ & 1r-11v & Willem & Wainter \\
& & Zierikzee, ofM \\
& & Descriptio \\
& & de tota terra \\
& & promissionis cum \\
& & Iherusalem \\
& & (1r-43r) \\
& & \\
$\mathrm{II}^{12}$ & $12 \mathrm{r}-23 \mathrm{~V}$ & \\
$\mathrm{III}^{12}$ & $24 \mathrm{r}-35 \mathrm{~V}$ & \\
$\mathrm{IV}^{12}$ & $36 \mathrm{r}-47 \mathrm{~V}$ &
\end{tabular}


(cont.)

\begin{tabular}{|c|c|c|c|c|}
\hline Quires & Folios & Contents & Decoration & Painter \\
\hline \multirow[t]{7}{*}{$\mathrm{V}^{12}$} & $48 \mathrm{r}-59 \mathrm{v}$ & Willem & & \\
\hline & & Walterzoon van & & \\
\hline & & Zierikzee, oFM & & \\
\hline & & Descriptio & & \\
\hline & & secunda terre & & \\
\hline & & sancte & & \\
\hline & & $\left(43^{r-66 v}\right)$ & & \\
\hline \multirow[t]{5}{*}{$\mathrm{VI}^{12}$} & 6 or-71v & Descriptio & & \\
\hline & & brevis terre & & \\
\hline & & promissionis & & \\
\hline & & $(67 r-6 g v)$ & & \\
\hline & & 7or-71v blank & & \\
\hline \multirow[t]{11}{*}{$\mathrm{VII}^{12}$} & $72 \mathrm{r}-83 \mathrm{v}$ & De situ Terre & & \\
\hline & & sancte & & \\
\hline & & $(72 \mathrm{rv})$ & & \\
\hline & & De duodecim & & \\
\hline & & regnis & & \\
\hline & & $(72 v-76 v)$ & & \\
\hline & & St Odericus de & & \\
\hline & & Pordenone, ofM & & \\
\hline & & Peregrinatio sive & & \\
\hline & & itinerarium & & \\
\hline & & $\left(77^{r}-105 r\right)$ & & \\
\hline VIII $^{12}$ & $84 \mathrm{r}-95^{\mathrm{V}}$ & & & \\
\hline $\mathrm{IX}^{12-29(2 \text { before }}$ & $96 \mathrm{r}-105 \mathrm{v}$ & 105v blank & & \\
\hline 106) & & & & \\
\hline \multirow[t]{9}{*}{$X^{12-1(\text { before 106) }}$} & $106 r-16 v$ & De Flebotomia & 11or Bloodletting & \\
\hline & & $(106 r-09 v)$ & Zodiac man & \\
\hline & & Computus & [full-p. drawing] & \\
\hline & & $(110 v-12 r)$ & & \\
\hline & & Cisiojanus & & \\
\hline & & $(112 v-15 r)$ & & \\
\hline & & De Natuurkunde & & \\
\hline & & van het geheelal & & \\
\hline & & $\left(115^{r-51 v}\right)$ & & \\
\hline
\end{tabular}


(cont.)

\begin{tabular}{|c|c|c|c|c|}
\hline Quires & Folios & Contents & Decoration & Painter \\
\hline \multirow[t]{21}{*}{$\mathrm{XI}^{12}$} & $117 \mathrm{r}-28 \mathrm{v}$ & & $\begin{array}{l}\text { 119r Scheme of the } \\
\text { planets [drawing] }\end{array}$ & \\
\hline & & & $\begin{array}{l}\text { 12or Scheme of the Sun } \\
\text { and Moon [min.] }\end{array}$ & \\
\hline & & & 121r Scheme of signs & \\
\hline & & & of the zodiac, and & \\
\hline & & & sun, moon and stars & \\
\hline & & & [drawing] & \\
\hline & & & $\begin{array}{l}\text { 122v Scheme of the } \\
\text { astrological houses } \\
\text { [drawing] }\end{array}$ & \\
\hline & & & 123r Luna [min.] & $\mathrm{Z}$ \\
\hline & & & 123v Mercury & $\mathrm{Z}$ \\
\hline & & & [half-p. min.] & \\
\hline & & & 124r Venus [half-p. min.] & $\mathrm{Z}$ \\
\hline & & & 125r Sol [half-p. min.] & $\mathrm{Z}$ \\
\hline & & & 125v Mars [half-p. min.] & $\mathrm{Z}$ \\
\hline & & & $\begin{array}{l}\text { 126r Jupiter [half-p. } \\
\text { min.] }\end{array}$ & $\mathrm{Z}$ \\
\hline & & & $\begin{array}{l}\text { 126v Saturn [half-p. } \\
\text { min.] }\end{array}$ & $\mathrm{Z}$ \\
\hline & & & $\begin{array}{l}\text { 127r Firmament with } \\
\text { stars [min.] }\end{array}$ & \\
\hline & & & 128r Sun [min.] & \\
\hline & & & 128v Moon [min.] & \\
\hline & & & $\begin{array}{l}\text { Mercury as a star } \\
\text { [min.] }\end{array}$ & \\
\hline & & & Venus as a star & \\
\hline & & & {$[\mathrm{min}]$.} & \\
\hline \multirow[t]{5}{*}{$\mathrm{XII}^{12}$} & $129 \mathrm{r}-4 \mathrm{OV}$ & & 129r Mars as a star & \\
\hline & & & [min.] & \\
\hline & & & Jupiter as a star & \\
\hline & & & {$[\min ]$.} & \\
\hline & & & Saturn as a star & \\
\hline
\end{tabular}


(cont.)

\begin{tabular}{|c|c|c|c|c|}
\hline Quires & Folios & Contents & Decoration & Painter \\
\hline & & & $\begin{array}{l}\text { 129v Firmament with } \\
\text { stars [min.] } \\
\text { 13or Comet [min.] } \\
\text { 131r Comets [min.] } \\
\text { 133r Flash of lightning } \\
\text { [min] } \\
\text { 134v Ice storm [min.] } \\
\text { 136r Rainbow [min.] } \\
\text { 136v Lunar halo [min.] } \\
\text { 137v Moon [min.] } \\
\text { 138r Scheme of the } \\
\text { firmament [drawing] } \\
\text { 138v Lunar halo } \\
\text { [drawing] }\end{array}$ & \\
\hline & & & 139v Aries [min.] & $\mathrm{Z}$ \\
\hline \multirow[t]{11}{*}{$\mathrm{XIII}{ }^{12}$} & $141 \mathrm{r}-5^{2 \mathrm{~V}}$ & 152rv blank & 141r Taurus [min.] & $\mathrm{Z}$ \\
\hline & & & 142r Gemini [min.] & $\mathrm{Z}$ \\
\hline & & & 143r Cancer [min.] & $\mathrm{Z}$ \\
\hline & & & 144r Leo [min.] & $\mathrm{Z}$ \\
\hline & & & 145 r Virgo [min] & $\mathrm{Z}$ \\
\hline & & & 146v Libra [min.] & $\mathrm{Z}$ \\
\hline & & & 147v Scorpio [min.] & $\mathrm{Z}$ \\
\hline & & & 148r Sagittarius [min.] & $\mathrm{Z}$ \\
\hline & & & 149r Capricornus [min.] & $\mathrm{Z}$ \\
\hline & & & 15or Aquarius [min.] & $\mathrm{Z}$ \\
\hline & & & 151r Pisces [min.] & $\mathrm{Z}$ \\
\hline $\mathrm{XIV}^{4}$ & $153^{r-56 v}$ & $\begin{array}{l}\text { Medical recipes } \\
\left(153^{r}-56 \mathrm{r}\right) \\
\text { Rules for } \\
\text { punctuation } \\
(156 \mathrm{v})\end{array}$ & & \\
\hline
\end{tabular}

